\title{
Human and Monkey Striatal Interneurons Are Derived from the Medial Ganglionic Eminence But Not from the Adult Subventricular Zone
}

\author{
๑DCongmin Wang, ${ }^{1,2 *}$ Yan You, ${ }^{1 *}$ Dashi Qi, ${ }^{1,3 *}$ Xing Zhou, ${ }^{1}$ Lei Wang, ${ }^{4}$ Song Wei, ${ }^{1}$ Zhuangzhi Zhang, ${ }^{1}$ Weixi Huang, ${ }^{1}$ \\ Zhidong Liu, ${ }^{1}$ Fang Liu, ${ }^{1}$ Lan $\mathrm{Ma},{ }^{1}$ and Zhengang Yang ${ }^{1}$ \\ ${ }^{1}$ Institutes of Brain Science and State Key Laboratory of Medical Neurobiology, Fudan University, Shanghai 200032, People's Republic of China, \\ ${ }^{2}$ Department of Neurology, Affiliated Hospital of Hebei University of Engineering, Handan 056002, Hebei Province, People's Republic of China, \\ ${ }^{3}$ Department of Neurobiology, Xuzhou Medical College, Xuzhou 221009, Jiangsu Province, People's Republic of China, and ${ }^{4}$ Department of Human \\ Anatomy, Hebei Medical University, Shijiazhuang 050017, Hebei Province, People's Republic of China
}

In adult rodent and monkey brains, newly born neurons in the subventricular zone (SVZ) in the wall of the lateral ventricle migrate into the olfactory bulb $(\mathrm{OB})$ via the rostral migratory stream (RMS). A recent study reported that interneurons are constantly generating in the adult human striatum from the SVZ. In contrast, by taking advantage of the continuous expression of Sp8 from the neuroblast stage through differentiation into mature interneurons, we found that the adult human SVZ does not generate new interneurons for the striatum. In the adult human SVZ and RMS, very few neuroblasts were observed, and most of them expressed the transcription factor Sp8. Neuroblasts in the adult rhesus monkey SVZ-RMS-OB pathway also expressed Sp8. In addition, we observed that Sp8 was expressed by most adult human and monkey OB interneurons. However, very few $\mathrm{Sp} 8+$ cells were in the adult human striatum. This suggests that neuroblasts in the adult human SVZ and RMS are likely destined for the OB, but not for the striatum. BrdU-labeling results also revealed few if any newly born neurons in the adult rhesus monkey striatum. Finally, on the basis of transcription factor expression, we provide strong evidence that the vast majority of interneurons in the human and monkey striatum are generated from the medial ganglionic eminence during embryonic developmental stages, as they are in rodents. We conclude that, although a small number of neuroblasts exist in the adult human SVZ, they do not migrate into the striatum and become mature striatal interneurons.

Key words: human; interneurons; neurogenesis; Sp8; striatum; SVZ

\section{Introduction}

The basal ganglia are involved in many mammalian neurobiological processes including the following: control of voluntary motor movements, procedural learning, and cognition (Leisman and Melillo, 2013). The striatum is the largest component of the basal ganglia. The monkey and human striatum can be easily anatomically subdivided into the caudate nucleus and putamen, whereas no clear division is observed in the mouse striatum. The vast majority of neurons (90-95\%) in the striatum are GABAergic medium-sized spiny projection neurons, which can be classified

\footnotetext{
Received May 1, 2014; revised June 27, 2014; accepted July 3, 2014.

Author contributions:C.W.,Y.Y., D.Q., and Z.Y. designed research;C.W., Y.Y., D.Q., X.Z., L.W., S.W., Z.Z., W.H., Z.L., F.L., and L.M. performed research; C.W., Y.Y., D.Q., X.Z., F.L., L.M., and Z.Y. analyzed data; Z.Y. wrote the paper.

This work was supported by National Basic Research Program of China Grant 2011CB504400, and by National Natural Science Foundation of China Grants 31121061 and 91232723 . We thank Chinese Brain Bank Center, Wuhan, People's Republic of China; Red Cross Society of China; and Shanghai Branch at Fudan University for providing access to donated human brains.

${ }^{*}$ C.W., Y.Y., and D.Q. contributed equally to this work.

The authors declare no competing financial interests.

Correspondence should be addressed to Dr. Zhengang Yang, Institutes of Brain Science and State Key Laboratory of Medical Neurobiology, Fudan University, 138 Yi Xue Yuan Road, Shanghai 200032, People's Republic of China. E-mail: yangz@fudan.edu.cn.

DOI:10.1523/JNEUROSCI.1758-14.2014

Copyright $\odot 2014$ the authors $\quad 0270-6474 / 14 / 3410906-18 \$ 15.00 / 0$
}

into striatonigral (direct pathway) and striatopallidal (indirect pathway) subtypes (Gerfen, 1992; Cicchetti et al., 2000). About $5-10 \%$ of striatal neurons are aspiny interneurons, which can be categorized into large ChAT immunoreactive $(+)$ cholinergic cells and medium-sized GABAergic cells, mainly including parvalbumin (PV)+, somatostatin (SOM)/neuropeptide Y (NPY)/ neuronal nitric oxide synthase (nNOS)-triple+, and calretinin (CR) + interneurons (Kawaguchi et al., 1995; Cicchetti et al., 2000).

During early embryonic development, neuroepithelial cells, and radial glia function as primary neural stem cells in the mouse lateral ganglionic eminence (LGE) and directly give rise to striatal projection neurons (Deacon et al., 1994; Olsson et al., 1995; Anderson et al., 1997; Wichterle et al., 2001). The caudal ganglionic eminence (CGE) may not produce striatal projection neurons (Flames et al., 2007; Long et al., 2009; Waclaw et al., 2009; Fishell and Rudy, 2011). Studies using retroviral labeling or genetic fatemapping approaches in mice demonstrate that the vast majority of striatal interneurons are derived from Nkx2-1-expressing primary neural stem cells in the medial ganglionic eminence (MGE) and the preoptic area (POA; Marin et al., 2000; Xu et al., 2008). At the end of embryonic development, radial glia in the LGE begin to convert into radial astrocytes (B1 cells) that continue to function as primary neural stem cells in the lateral wall of the lateral 

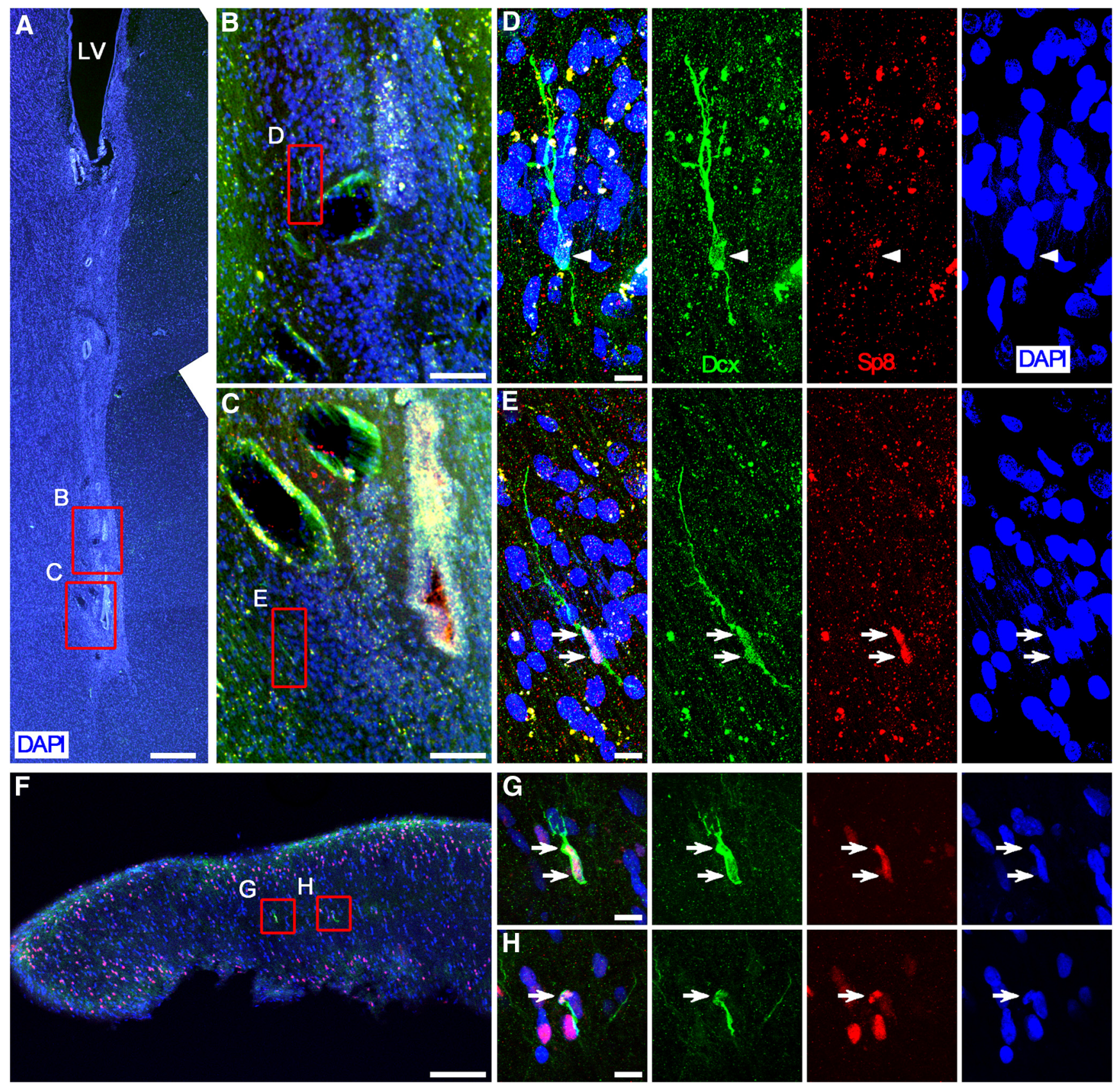

Figure 1. Most neuroblasts in the adult human SVZ and RMS express Sp8. A, DAPI-stained coronal section of the adult human brain shows the SVZ and ventral extension of the lateral ventricle (LV). Many small canals formed by ependymal cells were observed. $B, C$, Photomicrographs show Dcx/Sp8 double immunostaining in boxed areas in $A$. $D, E$, Higher-magnification images of boxed areas in $\boldsymbol{B}$ and $\boldsymbol{C}$ show $D c x+/ S p 8$-immunonegative cell ( $\boldsymbol{D}$, arrowhead) and $D c x+/ S p 8+$ cells ( $\boldsymbol{E}$, arrows). $\boldsymbol{F}$, Dcx/Sp8 double-immunostained coronal (transverse) section of the adult human olfactory tract. $\mathbf{G}, \boldsymbol{H}$, Higher-magnification images of boxed areas in $\boldsymbol{F}$ show $D c x+/$ Sp8 + cells (arrows). Scale bars: $\boldsymbol{A}, 500 \mu \mathrm{m} ; \boldsymbol{B}, \boldsymbol{C}, \boldsymbol{F}, 100 \mu \mathrm{m} ; \boldsymbol{D}, \boldsymbol{E}, \boldsymbol{G}, \boldsymbol{H}, 10 \mu \mathrm{m}$.

ventricle of the postnatal and adult mouse brain. Similarly, radial glia in the medial, dorsal, lateral, and ventral neocortex (pallium) also convert into subventricular zone (SVZ) neural stem cells (Kriegstein and Alvarez-Buylla, 2009). Notably, the MGE and POA only make a minor contribution to the adult SVZ neural stem cells (Young et al., 2007; Xu et al., 2008; Merkle et al., 2014).

In the normal mouse brain, the main function of SVZ neural stem cells ( $\mathrm{B} 1$ cells) is generating interneurons for the olfactory bulb (OB) throughout life (Doetsch et al., 1999; Mirzadeh et al., 2008). In the embryonic and neonatal human brain, massive migrating neuroblasts have been observed in the SVZ-rostral migratory stream (RMS)-OB pathway (Guerrero-Cázares et al., 2011; Wang et al., 2011; Ma et al., 2013). However, these robust streams of neuroblasts become depleted rapidly during the first year of life (Sanai et al., 2011). In the adult human brain, only very few neuroblasts in the ventral-most SVZ and RMS are observed (Wang et al., 2011).

More recently, an unexpected finding suggested that adult human SVZ neural stem cells also produced newly born CR + and $\mathrm{NPY}+$ interneurons for the striatum, with $25 \%$ striatal neurons turnover (Ernst et al., 2014). In the present study, however, we present compelling results that suggest a very different conclusion.

\section{Materials and Methods}

Human and monkey tissue collection. All human tissues (Wang et al., 2011; Ma et al., 2013) were collected with informed consent and in ac- 


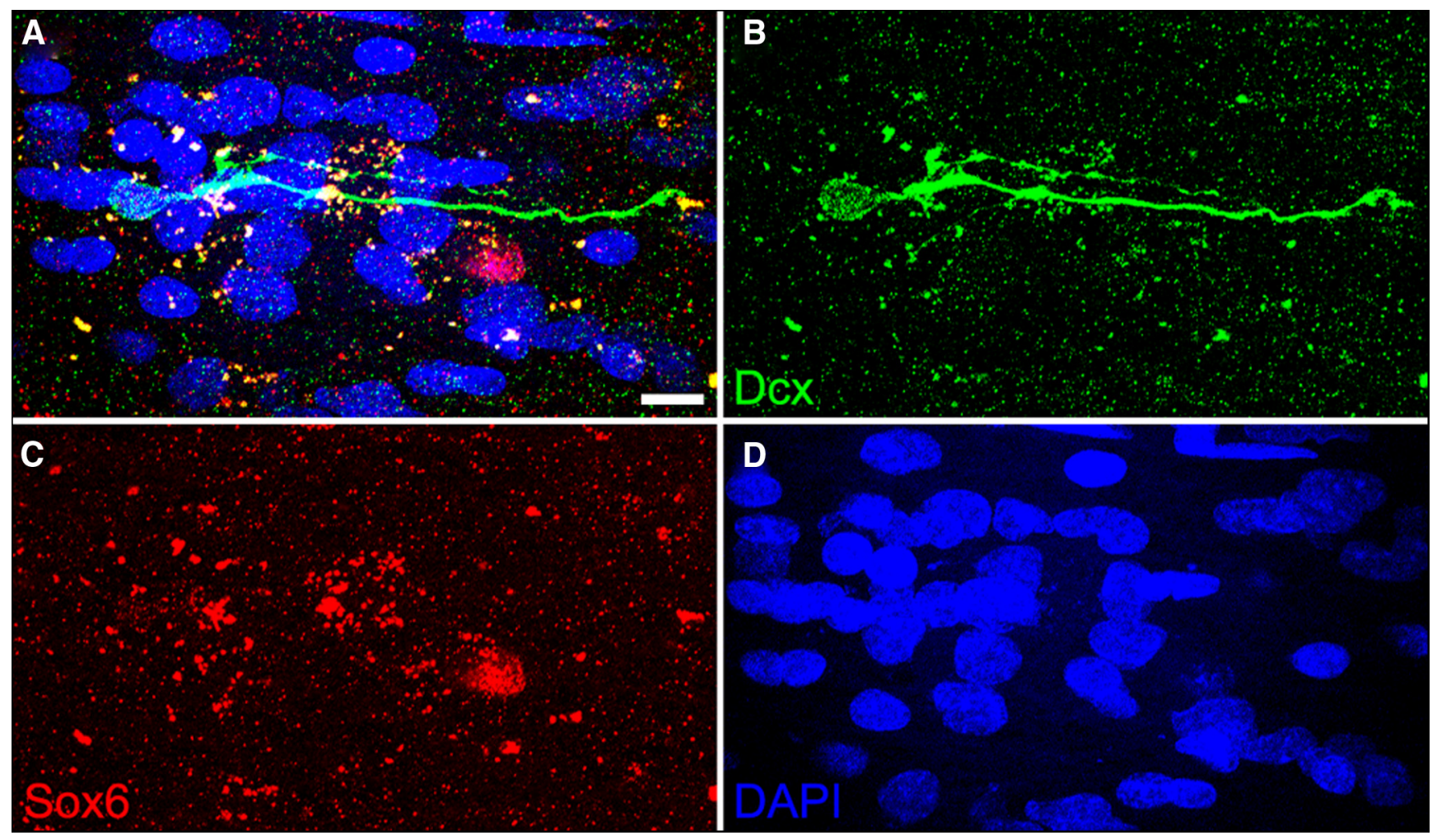

Figure 2. Neuroblasts in the adult human SVZ and RMS do not express Sox6. $A-D$, The photomicrograph shows that a $D c x+$ cell in the ventral extension of the lateral ventricle did not express Sox6. Scale bar, $10 \mu \mathrm{m}$.

cordance with institutional guidelines and the study design was approved by the institutional review board (Ethics Committee) of Shanghai Medical College of Fudan University (20110307-085, 20120302-099).

Human fetal brain at gestation week (GW) 18 (male) was obtained at autopsy $\sim 3 \mathrm{~h}$ after spontaneous abortion. Brain tissue was fixed in $4 \%$ PFA at $4^{\circ} \mathrm{C}$ for $3-5 \mathrm{~d}$ and then cryoprotected in $30 \%$ sucrose in $0.1 \mathrm{M} \mathrm{PB}$ for $72 \mathrm{~h}$ at $4^{\circ} \mathrm{C}$. The brain tissue samples were frozen in embedding medium (OCT, Sakura Finetek) on a dry ice/ethanol slush. Adult human brains were obtained at autopsy from subjects of different ages with no history of neuropathology, as previously described (Wang et al., 2011; $\mathrm{Ma}$ et al., 2013). Brains were fixed by bilateral perfusion with $4 \%$ PFA for $1-2 \mathrm{~h}$ through the internal carotid arteries. The brains were then cut into 1.0- to 2.0-cm-thick slabs. The slabs were postfixed in 4\% PFA for 1 week and then cryoprotected in $30 \%$ sucrose for $72 \mathrm{~h}$ at $4^{\circ} \mathrm{C}$. The brain tissue samples were frozen in OCT. In the present study, we focused our analysis on three adult human brains (from a male, 35 years of age, who died of heart failure; from a male, 39 years of age, who died of pulmonary failure; and female, 60 years of age, who fell to her death; Ma et al., 2013).

All animal care and experiments were conducted in accordance with institutional guidelines. Postnatal day 0 ( $\mathrm{P} 0$, male), postnatal month 6 (P6M, male) and P17M (male), and adult rhesus (Macaca mulatta) monkeys ( $>6$ years of age, 1 male and 3 females; Wang et al., 2011; Ma et al., 2013) were obtained from the Kunming Primate Research Center of Chinese Academy of Sciences at Kunming, People's Republic of China and Suzhou Xishan Zhongke Laboratory Animal Co., Ltd., Suzhou, People's Republic of China. Monkeys were deeply anesthetized and then perfused with PBS followed by $4 \%$ PFA. The brains were postfixed with $4 \%$ PFA for $12-48 \mathrm{~h}$, then cut coronally into $\sim 1.0-2.0 \mathrm{~cm}$ slabs, and cryoprotected in $30 \%$ sucrose in $0.1 \mathrm{M} \mathrm{PB}$ at $4^{\circ} \mathrm{C}$ for $72 \mathrm{~h}$. The brain tissue samples were frozen in OCT.

BrdU injections. The S-phase marker bromodeoxyuridine (BrdU; 50 $\mathrm{mg} / \mathrm{kg}$ body weight; Sigma) was injected intraperitoneally into two adult rhesus monkeys (7.0 and 7.5 years old) twice daily for $5 \mathrm{~d}$ (total, 10 times). Monkeys were perfused 10 or 15 weeks after BrdU injections.

Immunohistochemistry. Immunohistochemical staining was performed on 30-60 $\mu \mathrm{m}$ free-floating serial coronal sections in 12- or 24- well cell culture plates. Most sections were subjected to an antigen retrieval protocol. Briefly, cryosections were mounted on glass slides and boiled in a microwave oven in $10 \mathrm{~mm}$ sodium citrate, $\mathrm{pH}$ 6.0. Sections for BrdU immunostaining were pretreated with $2 \mathrm{~N} \mathrm{HCl}$ for $1 \mathrm{~h}$ at room temperature to denature the DNA. Sections were blocked for $1 \mathrm{~h}$ in TBS with $1 \%$ Triton X-100 and 10\% normal donkey serum. All primary antibodies were incubated for $48 \mathrm{~h}$ at $4^{\circ} \mathrm{C}$. We used the following primary antibodies: rat anti-BrdU (1:1000; OBT0030, Accurate Chemical and Scientific Corporation), goat anti-ChAT (1:200; AB144, Millipore), rabbit anti-calbindin-D-28k (CB;1:3000; CB38a, Swant), rabbit anti-CR (1: 3000; 7699/3H, Swant), mouse anti-CR (1:1000; 6B3, Swant), goat antidoublecortin (Dcx; 1:200; sc-8066, Santa Cruz Biotechnology), rabbit anti-Dcx (1:800; ab-18723, Abcam), mouse anti-NeuN (1:500; MAB377, Millipore), rabbit anti-Nkx2-1 (also known as TTF-1; 1:500; sc-13040, Santa Cruz Biotechnology), rabbit anti-nNOS (1:500; 24287, Immunostar), rabbit anti-NPY (1:300; 22940, Immunostar), mouse anti-PV (1: 1000; P3088, Sigma), goat anti-SOM (1:200; sc-7819, Santa Cruz Biotechnology), rabbit anti-SOM (1:200; sc-13099, Santa Cruz Biotechnology), goat anti-Sp8 (1:500; sc-104661, Santa Cruz Biotechnology), rabbit anti-Sox6 (1:3000; ab30455, Abcam), mouse anti-polysialylated neural cell adhesion molecule (PSA-NCAM; 1:600; MAB5324, Millipore), and mouse anti-tyrosine hydroxylase (TH; 1:200; MAB318, Millipore).

Secondary antibodies against the appropriate species were incubated for $4 \mathrm{~h}$ at room temperature (all from The Jackson Laboratory; 1:300). Fluorescently stained sections were counterstained with DAPI (200 ng/ $\mathrm{ml}$; Sigma) for 2-5 min, and coverslipped with Gel/Mount (Biomeda). When needed, Autofluorescence Eliminator Reagent (catalog \#2160, Millipore) was used to reduce lipofuscin autofluorescence in human brain sections. Diaminobenzidine was used to visualize the reaction product for bright-field staining sections.

Microscopy. Fluorescently immunostained sections were analyzed on an Olympus FV1000 confocal laser-scanning microscope. Confocal Z sectioning was performed using a $20 \times$ [numerical aperture (NA) $=$ $0.75], 40 \times(\mathrm{NA}=1.00)$, or $60 \times(\mathrm{NA}=1.42)$ objective for single, double, and triple immunostaining. Images were cropped, adjusted, and optimized in Adobe Photoshop CS2. All high-magnification images shown in 

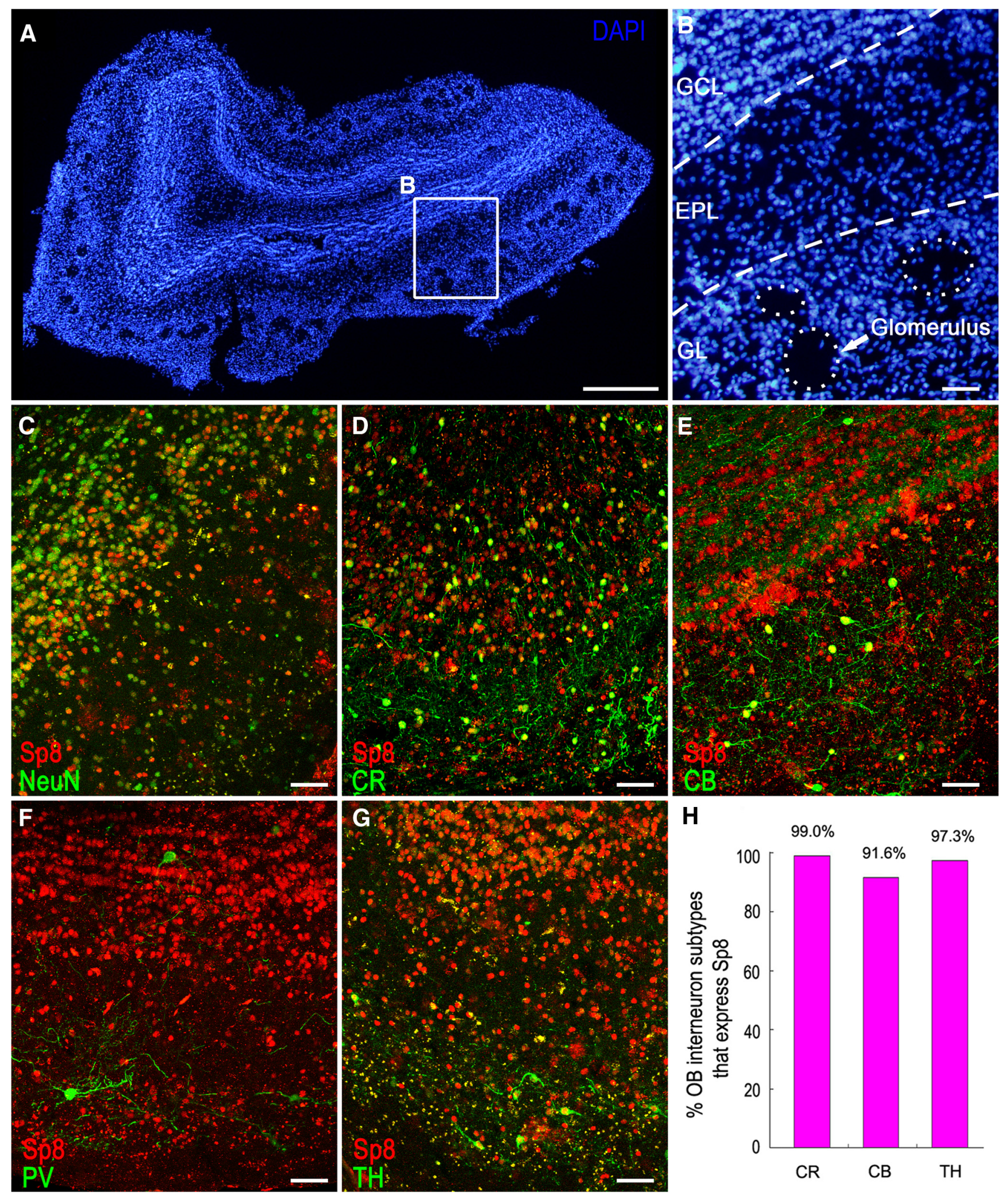

Figure 3. Most interneurons in the adult human OB express Sp8.A, DAPI-stained coronal section of the adult human OB. $B$, Higher-magnification image of the boxed area in $A$ shows the GCL, EPL, and $G L$ of the $0 B$. $(-E, G$, The majority of NeuN $+(\boldsymbol{C}),(R+(\boldsymbol{D}),(B+(\boldsymbol{E})$, and $T H+(\boldsymbol{G})$ cells expressed Sp8. Very few PV + cells $(\boldsymbol{F})$ were in the GCL and $G L$, and none were in the EPL; they did not express Sp8. $\boldsymbol{H}$, Quantification of the above double-immunostaining experiments. Scale bars: $\boldsymbol{A}, 500 \mu \mathrm{m} ; \boldsymbol{B}-\mathbf{G}, 50 \mu \mathrm{m}$.

this study were generated using a confocal laser-scanning microscope. Images of enzyme histochemistry-labeled sections and some fluorescently immunolabeled sections were acquired using an Olympus BX 51 microscope.
Cell counting. Brains from P0, P6M, and P17M monkeys; a GW18 human fetus; and a 39-year-old human were selected for quantification. We counted immunopositive cells from at least three sections from the $\mathrm{OB}$ and striatum of monkeys and humans using an Olympus BX 51 microscope. 


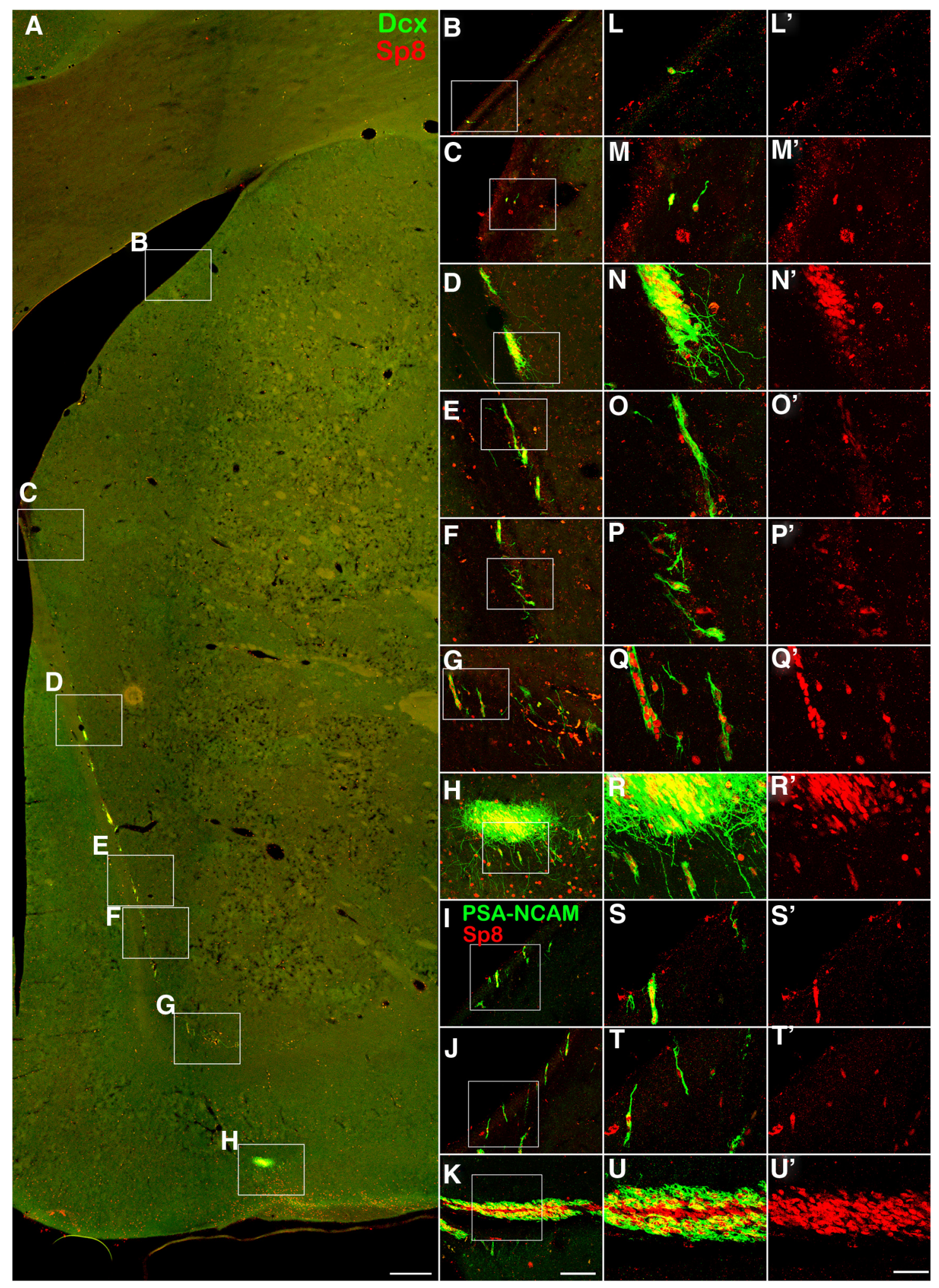

Figure 4. Most neuroblasts in the adult rhesus monkey SVZ and RMS express Sp8. $\boldsymbol{A}, \mathrm{Dxx} / \mathrm{Sp} 8$ double-immunostained coronal section of the adult rhesus monkey brain. $\boldsymbol{B}$ - $\boldsymbol{H}$, Higher-magnification images of the boxed areas in $\boldsymbol{A}$. $\boldsymbol{L}-\boldsymbol{R}^{\prime}$, Higher-magnification images of the boxed areas in $\boldsymbol{B}-\boldsymbol{H}$ show that most Dcx + cells expressed Sp8. $\boldsymbol{I}-\boldsymbol{K}, \mathrm{PSA}-\mathrm{NCAM} / \mathrm{Sp}$ 8 double-immunostained coronal sections of the SVZ (I,J) and RMS (K).S-U', Higher-magnification images of the boxed areas in $\boldsymbol{I}-\boldsymbol{K}$ show that most PSA-NCAM+ cells expressed Sp8. Scale bars: $\boldsymbol{A}, 500 \mu \mathrm{m}$; (in $\boldsymbol{K}) \boldsymbol{B}-\boldsymbol{K}, 100 \mu \mathrm{m}$; (in $\boldsymbol{U}^{\prime}$ ) $\boldsymbol{L}-\boldsymbol{U}^{\prime}, 40 \mu \mathrm{m}$.

\section{Results}

Most migrating immature neurons in the adult human SVZ and RMS express the transcription factor Sp8

Our recent study has shown a robust migratory stream with massive Sp8+ immature neuroblasts in the LGE-RMS-OB pathway of the human and rhesus monkey fetal brain (Ma et al., 2013), consistent with previous observations from the developing mouse brain (Waclaw et al., 2006; Ma et al., 2012). In the adult mouse brain, most cells in the SVZ-RMS-OB pathway also express Sp8 (Waclaw et al., 2006; Wei et al., 2011; Chen et al., 2012); 


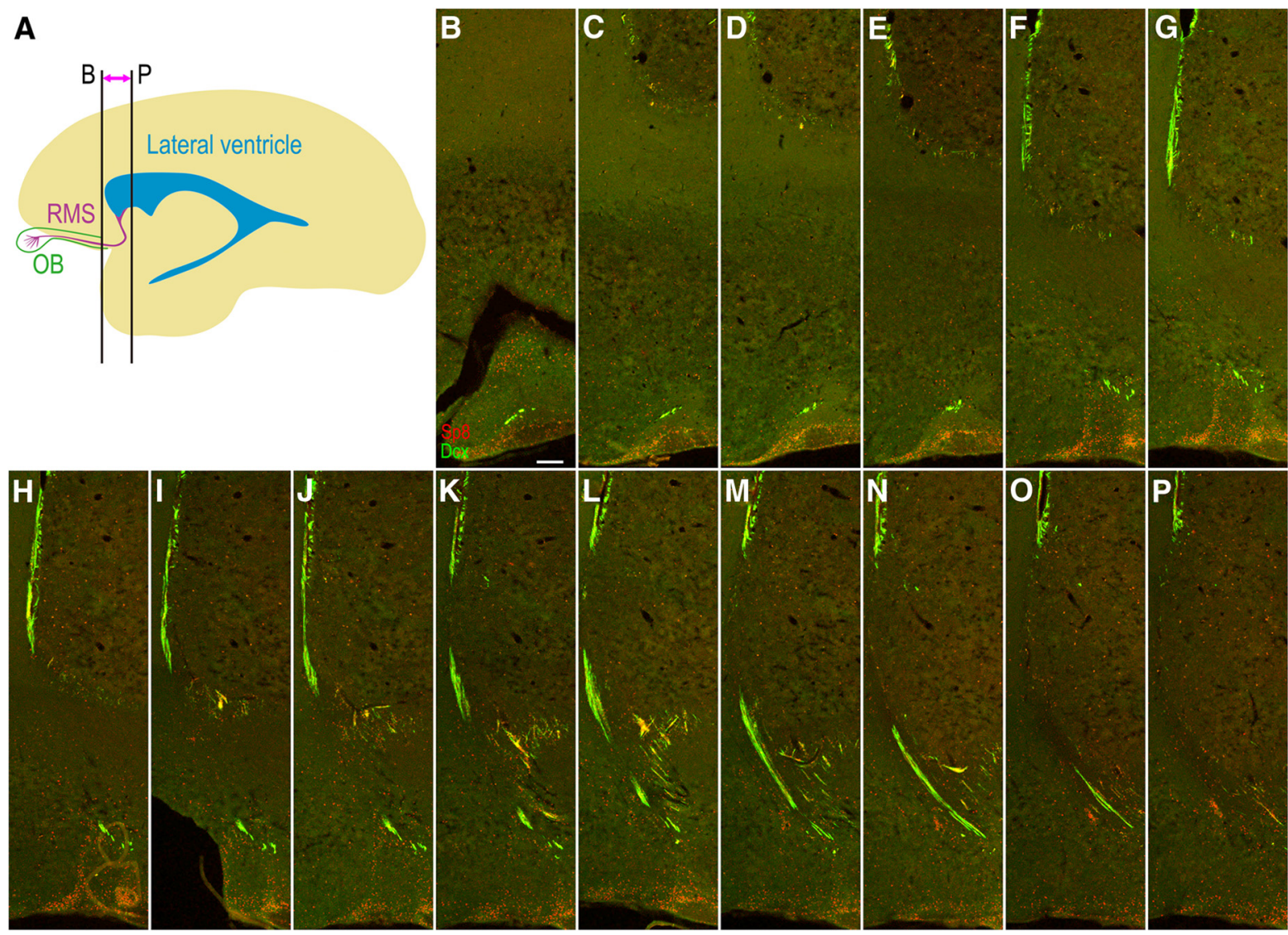

Figure 5. The general configuration of the RMS in the adult rhesus monkey brain. $A$, Sagittal view of the adult rhesus monkey RMS from the ventral extension of the front horn of the lateral ventricle to the olfactory tract and $\mathrm{OB} . \boldsymbol{B}-\boldsymbol{P}$, Fifteen Dcx/Sp8 double-immunostained serial coronal sections show the general configuration of the RMS in the adult rhesus monkey brain. Scale bar, $250 \mu \mathrm{m}$.
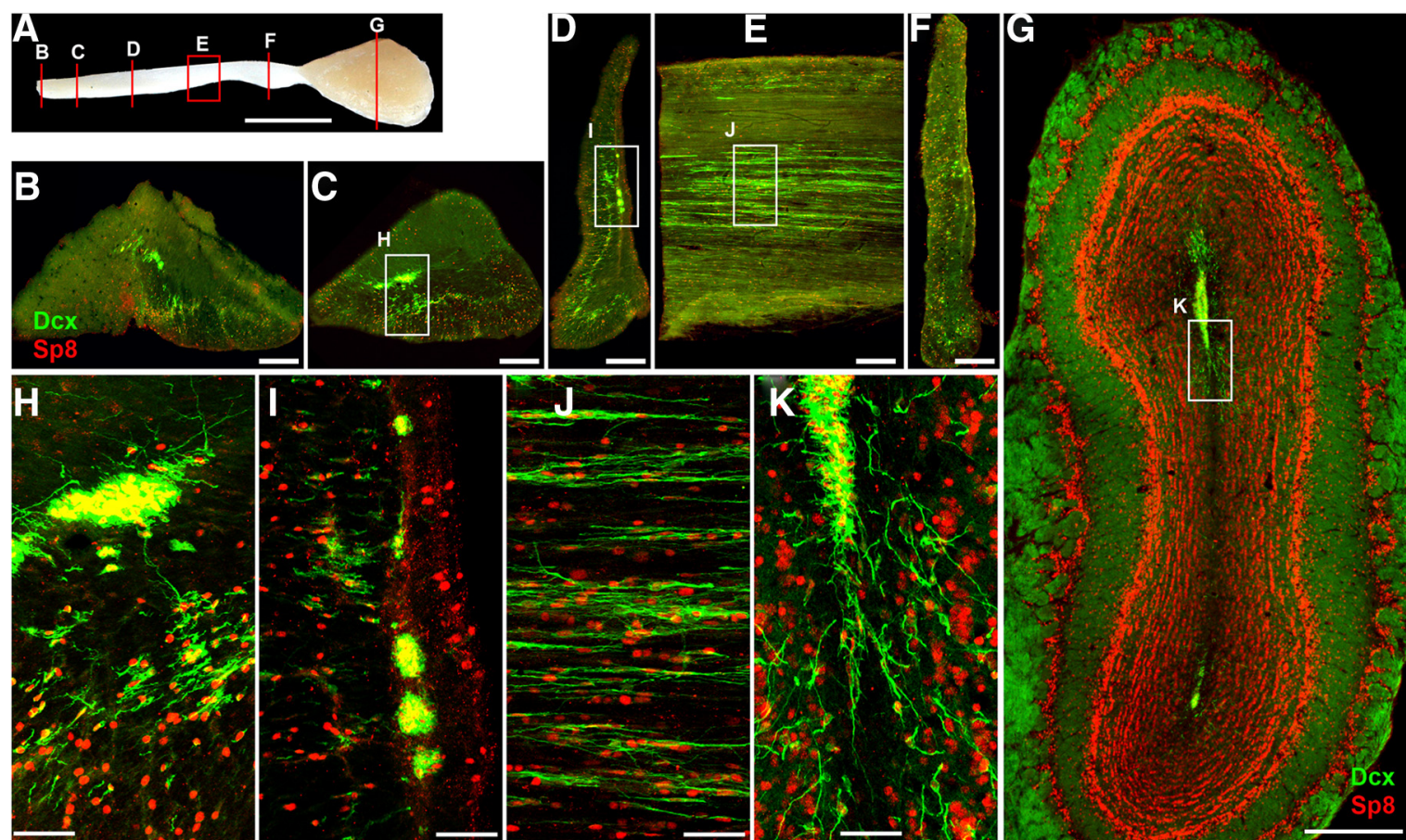

Figure 6. The majority of neuroblasts in the adult rhesus monkey olfactory tract and $O B$ express Sp8. $A$, The photograph of the adult rhesus monkey olfactory tract and $0 B$. B-D, $\boldsymbol{F}, \mathbf{G}, D(x / S p 8$ double-immunostained coronal (transverse) sections of the olfactory tract and $O B . \boldsymbol{E}, \mathrm{D} x \mathrm{x} / \mathrm{Sp} 8$ double-immunostained sagittal (longitudinal) section of the olfactory tract. $\boldsymbol{H}-\boldsymbol{K}$, Highermagnification images of the boxed areas in $\boldsymbol{C}, \boldsymbol{D}, \boldsymbol{E}, \boldsymbol{G}$ show that most Dex + cells expressed Sp8. Scale bars: $\boldsymbol{A}, 5 \mathrm{~mm} ; \boldsymbol{B}-\boldsymbol{F}, 200 \mu \mathrm{m} ; \boldsymbol{G}, 500 \mu \mathrm{m} ; \boldsymbol{H}-\boldsymbol{K}, 50 \mu \mathrm{m}$. 

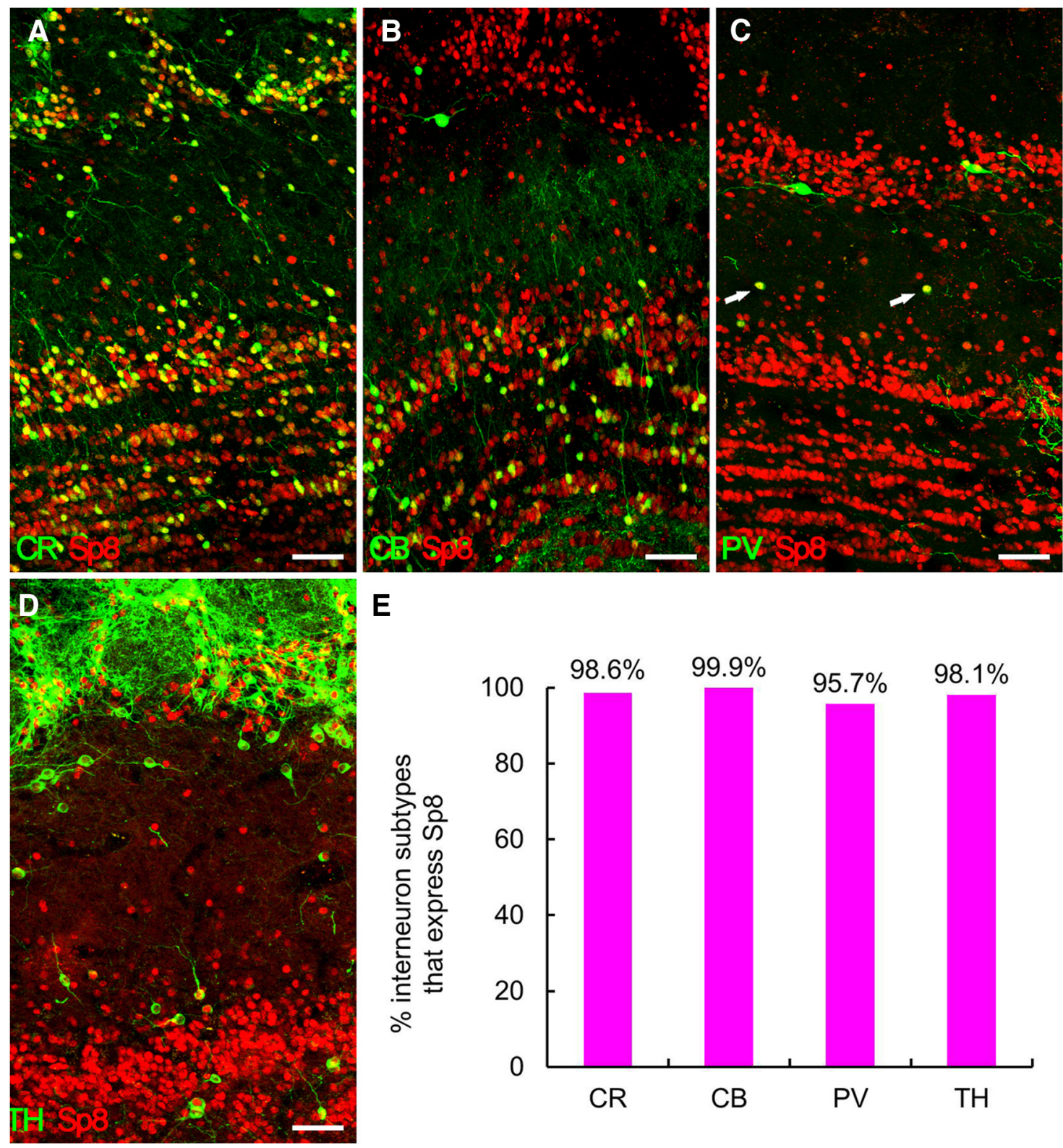

$\mathbf{E}$

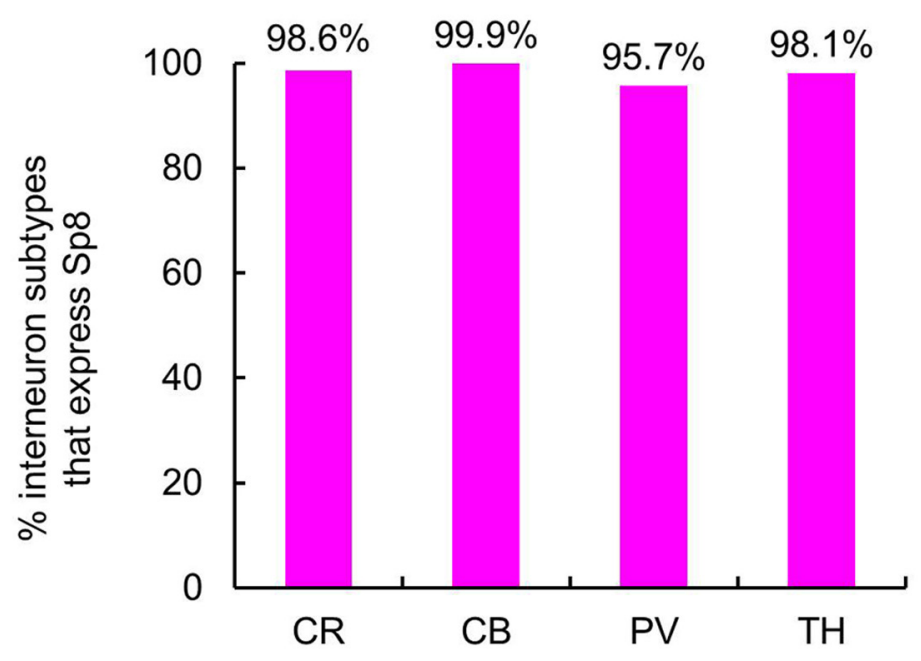

Figure 7. Most interneurons in the adult rhesus monkey OB express Sp8. $\boldsymbol{A}-\boldsymbol{D}, \mathrm{CR}+$ cells $(\boldsymbol{A})$ and $\mathrm{TH}+$ cells $(\boldsymbol{D})$ in the $0 B, C B+$ cells in the GCL $(\boldsymbol{B})$, and PV + cells $(\boldsymbol{C}$, arrows) in the EPL expressed Sp8. $\boldsymbol{E}$, Quantification of above double-immunostaining experiments. Scale bars: $\boldsymbol{A}-\boldsymbol{D}, 50 \mu \mathrm{m}$.

therefore, we first analyzed the expression of Sp8 in neuroblasts in the adult human SVZ and RMS. Similar to our previous findings (Wang et al., 2011), only very few scattered Dcx + cells were observed in the ventral-most SVZ, ventral extension of the lateral ventricle, RMS, and olfactory tract of the adult human brain (Fig. 1). No Dcx + cells were observed in the dorsal-lateral SVZ, lateral SVZ, striatum, and OB (Wang et al., 2011). We have previously also shown that these Dcx + cells in the adult human SVZ and RMS coexpressed typical markers of migratory immature neurons, PSA-NCAM and neuron-specific class III $\beta$-tubulin (Wang et al., 2011), suggesting that they are bona fide neuroblasts. Indeed, these Dcx + neuroblasts in the SVZ and RMS had an elongated morphology with unipolar or bipolar processes, typical migratory morphologies (Fig. 1; Wang et al., 2011). Dcx/Sp8 double immunostaining demonstrated that most $\mathrm{Dcx}+$ neuroblasts in the SVZ and RMS expressed Sp8 (66 Dcx +/Sp8 + cells of $85 \mathrm{Dcx}+$ cells; Fig. $1 A-H)$. We also examined whether these
Dcx + neuroblasts expressed Sox6; however, none of them expressed this MGE-derived cell marker (Azim et al., 2009; BatistaBrito et al., 2009; Fig. 2). These results suggest that most Dcx + migratory neuroblasts in the adult human ventral-most SVZ, ventral extension of the lateral ventricle, RMS, and olfactory tract are progeny from the LGE, but not the MGE, as Sp8 is not expressed in the MGE (Ma et al., 2012, 2013; Vogt et al., 2014).

\section{The majority of interneurons in the adult human $\mathrm{OB}$} express Sp8

We next examined the coexpression of $\mathrm{Sp} 8$ with the known markers of $\mathrm{OB}$ interneurons, including $\mathrm{CR}, \mathrm{CB}, \mathrm{PV}$, and $\mathrm{TH}$ in the adult human $\mathrm{OB}$ (Fig. $3 A$ ). We found that the vast majority of $\mathrm{CR}+, \mathrm{CB}+$, and $\mathrm{TH}+$ cells in the $\mathrm{OB}$ expressed $\mathrm{Sp} 8$ (Fig. $3 D, E, G, H)$. However, only very few $\mathrm{PV}+$ cells with larger soma were in the granule cell layer (GCL) and glomerular layer (GL); these cells did not express Sp8. Few if any PV + cells were ob- 

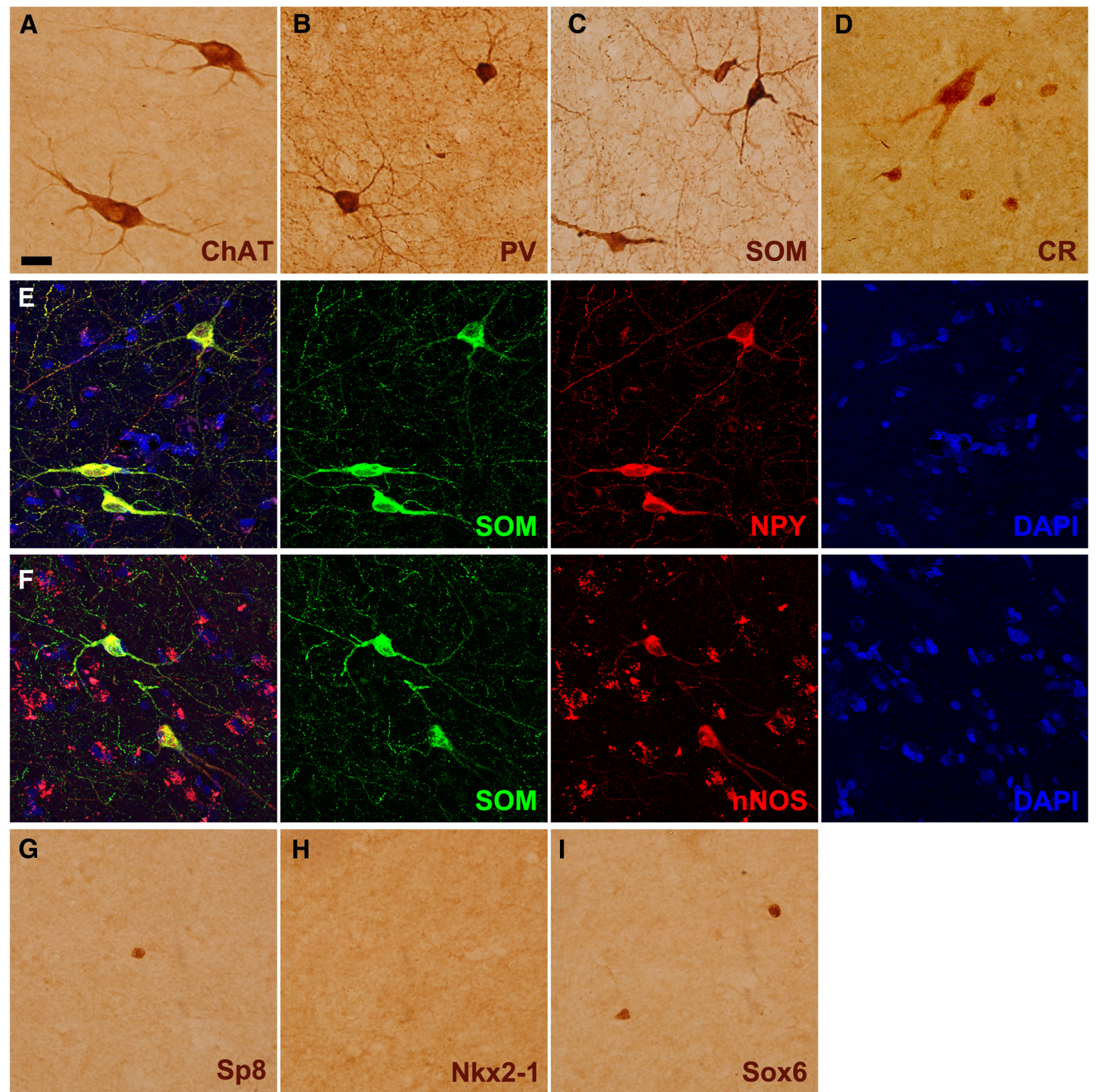

H

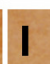

Figure 8. Interneuron and transcription factor expression in the adult human striatum. $A-D$, Photomicrographs of four different types of interneurons $(C h A T+, P V+, S O M+$, and $C R+)$ in the adult human striatum. Note that a large $C R+$ interneuron in $\boldsymbol{D}$ is shown. $\boldsymbol{E}, \boldsymbol{F}$, All SOM + interneurons in the human striatum expressed NPY and nNOS. G-I, Sp8+ and Sox6+ cells, but not Nkx2-1+ cells, were detected in the adult human striatum. Scale bars: (in $A) A-I, 20 \mu \mathrm{m}$.

served in the human OB external plexiform layer (EPL). This is surprising since many $\mathrm{PV}+$ cells are present in the mouse $\mathrm{OB}$ EPL, and all of them express Sp8 (Li et al., 2011). Our results suggest that Sp8 continues to be expressed in most differentiated $\mathrm{OB}$ interneurons that are generated from the LGE or postnatal SVZ. Thus, on the basis of the presence of the LGE-RMS-OB pathway containing massive migratory $\mathrm{Sp} 8+$ neuroblasts in the human fetal brain with the data described above, although Dcx + cells were not observed in the adult human OB (Wang et al., 2011), we infer that Dcx $+/ S p 8+$ cells in the adult human SVZ and RMS are likely to be destined to migrate to the OB.

\section{Sp8 is expressed in the adult rhesus monkey}

\section{SVZ-RMS-OB pathway}

It is well accepted that neuroblasts are generated in the adult monkey SVZ and migrate into the OB via the RMS (Kornack and Rakic, 2001a,b; Pencea et al., 2001; Bédard et al., 2002; GilPerotin et al., 2009; Sawamoto et al., 2011; Wang et al., 2011). To characterize the Sp8 expression in the adult rhesus monkey SVZRMS-OB pathway, we again performed double immunostaining for Dcx/Sp8 and PSA-NCAM/Sp8 in coronal brain sections. We found that most Dcx + and PSA-NCAM+ neuroblasts in the adult rhesus monkey (6 and 10 years old) SVZ, RMS, olfactory 


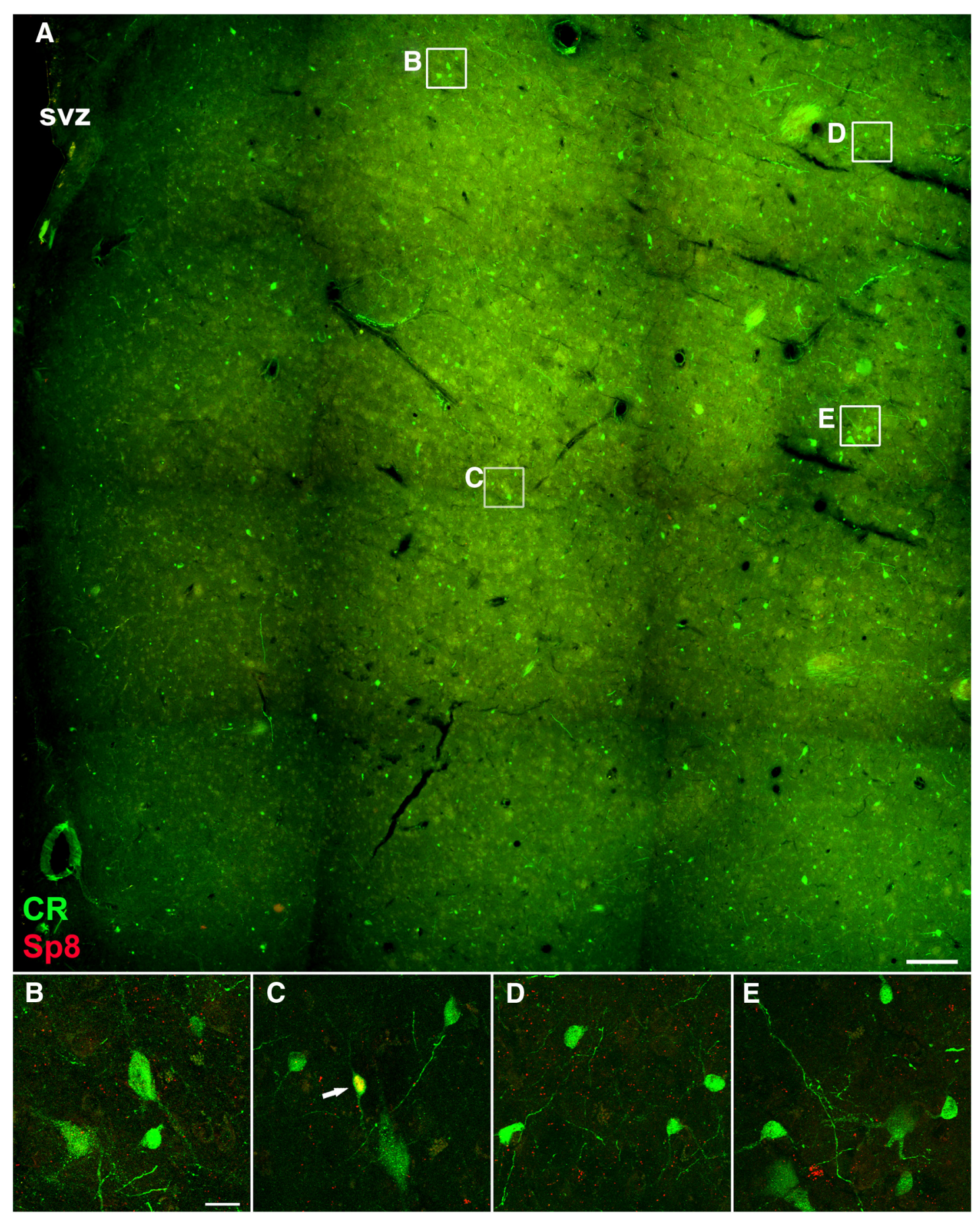

Figure 9. $C R+/ S p 8+$ cells in the adult human striatum are extremely rare. $\boldsymbol{A}, \mathrm{CR} / \mathrm{Sp} 8$ double-immunostained coronal section of the adult human striatum (caudate nucleus). $\boldsymbol{B}-\boldsymbol{E}$, Highermagnification images of boxed areas in $A$ show $C R+$ cells and $C R+/ S p 8+$ cell $(C$, arrow). Note that $C R+$ cells were abundant, whereas $C R+/ S p 8+$ cells were extremely rare in the adult human striatum. Scale bar: $\boldsymbol{A}, 500 \mu \mathrm{m}$; (in $\boldsymbol{B}) \boldsymbol{B}-\boldsymbol{E}, 20 \mu \mathrm{m}$.

tract, and OB expressed Sp8 (Fig. 4, 5, 6). Obviously, Dcx +/Sp8+ cells were more prominently observed in the ventral SVZ and RMS compared with those within dorsal, medial, and dorsallateral SVZ (Fig. 4, 5, 6). Serial Dcx/Sp8 double-immunostained coronal sections clearly showed the general configuration of the RMS in the adult rhesus monkey brain (Fig. $5 B-P$ ), which is significantly different from the rodent RMS. In brief, the RMS in the adult rhesus monkey brain extends from the anterior ventral horn of the lateral ventricle to the olfactory tract and then enters the OB (Fig. 5A; Wang et al., 2011). Except Dcx $+/$ Sp8 + cells in the
OB (Fig. 6G,K), most $\mathrm{CB}+$ cells in the GCL and PV+ cells in the EPL also expressed Sp8 (Fig. $7 B, C, E$ ). Those PV + cells with larger soma in the GCL and GL did not express Sp8 (Fig. 7C). We also noted that PV+ cells in the EPL of the rhesus monkey $\mathrm{OB}$ were present with very low cell density (Fig. 7C) compared with the mouse OB (Li et al., 2011). In addition, we observed that virtually all CR+ and $\mathrm{TH}+$ cells in all layers of the $\mathrm{OB}$ expressed Sp8 (Fig. $7 \mathrm{~A}, D, E$ ).

Together, the above results combined with our previous observations (Waclaw et al., 2006; Liu et al., 2009; Li et al., 2011; Wei et al., 2011; Chen et al., 2012; Ma et al., 2012, 2013) indicate that 


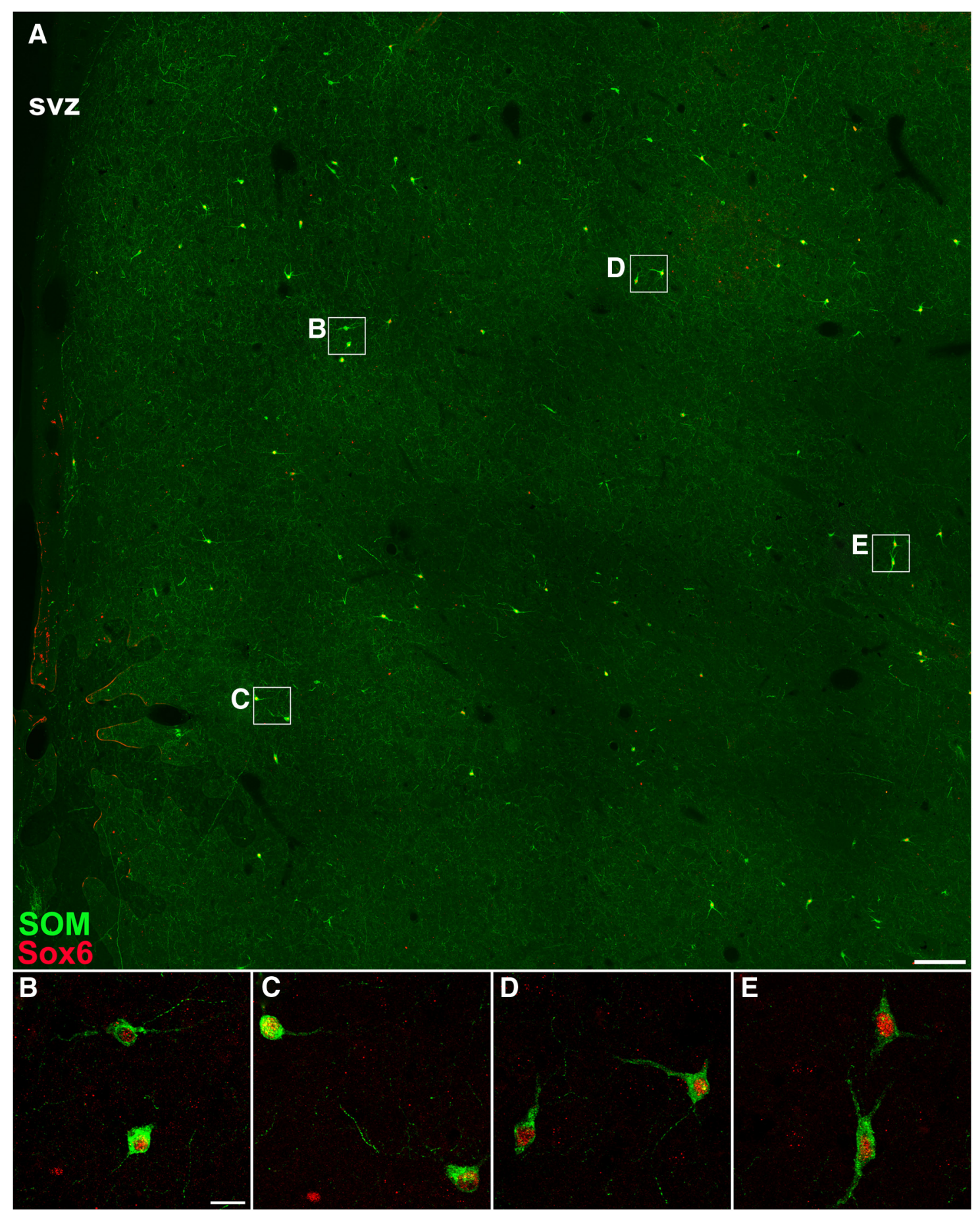

Figure 10. SOM+ cells in the adult human striatum express Sox6. $\boldsymbol{A}$, SOM/Sox6 double-immunostained coronal section of the adult human striatum (caudate nucleus). $\boldsymbol{B}-\boldsymbol{E}$, Highermagnification images of boxed areas in $\boldsymbol{A}$ show that virtually all SOM + cells expressed Sox6. Scale bars: $\boldsymbol{A}, 500 \mu \mathrm{m}$; (in $\boldsymbol{B}) \boldsymbol{B}-\boldsymbol{E} 20 \mu \mathrm{m}$.

strong expression of the zinc finger transcription factor Sp8 is the most prominent feature of the majority of cells in the SVZRMS-OB pathway, from the embryonic to adult stages, from immature migrating neuroblasts to mature interneurons, and from rodents to primates.

\section{Most interneurons in the adult human striatum are derived from the MGE}

A recent article suggested that neural stem/progenitor cells in the adult human SVZ continuously generate a subpopulation of $\mathrm{CR}+$ and NPY + interneurons for the striatum (Ernst et al.,
2014). Our previous studies have suggested that $S p 8$ can be also used as a marker for SVZ-derived newly born neurons in the rodent striatum, as $\mathrm{Sp} 8$ is continuously expressed from the neuroblast stage (e.g., Dcx + cells) through differentiation into mature neurons (e.g., NeuN+ cells; Liu et al., 2009; Wei et al., 2011). No evidence suggests that Sp8 is downregulated during the process of maturation of LGE-, CGE-, or postnatal SVZ-derived Sp8+ cells (Waclaw et al., 2006; Ma et al., 2012, 2013; Vogt et al., 2014). Therefore, we examined the colocalization of Sp8 with striatal interneurons in the adult human brain, mainly including $\mathrm{ChAT}+, \mathrm{PV}+, \mathrm{SOM}+$, and $\mathrm{CR}+$ cells $($ Fig. $8 A-D)$. Note that 

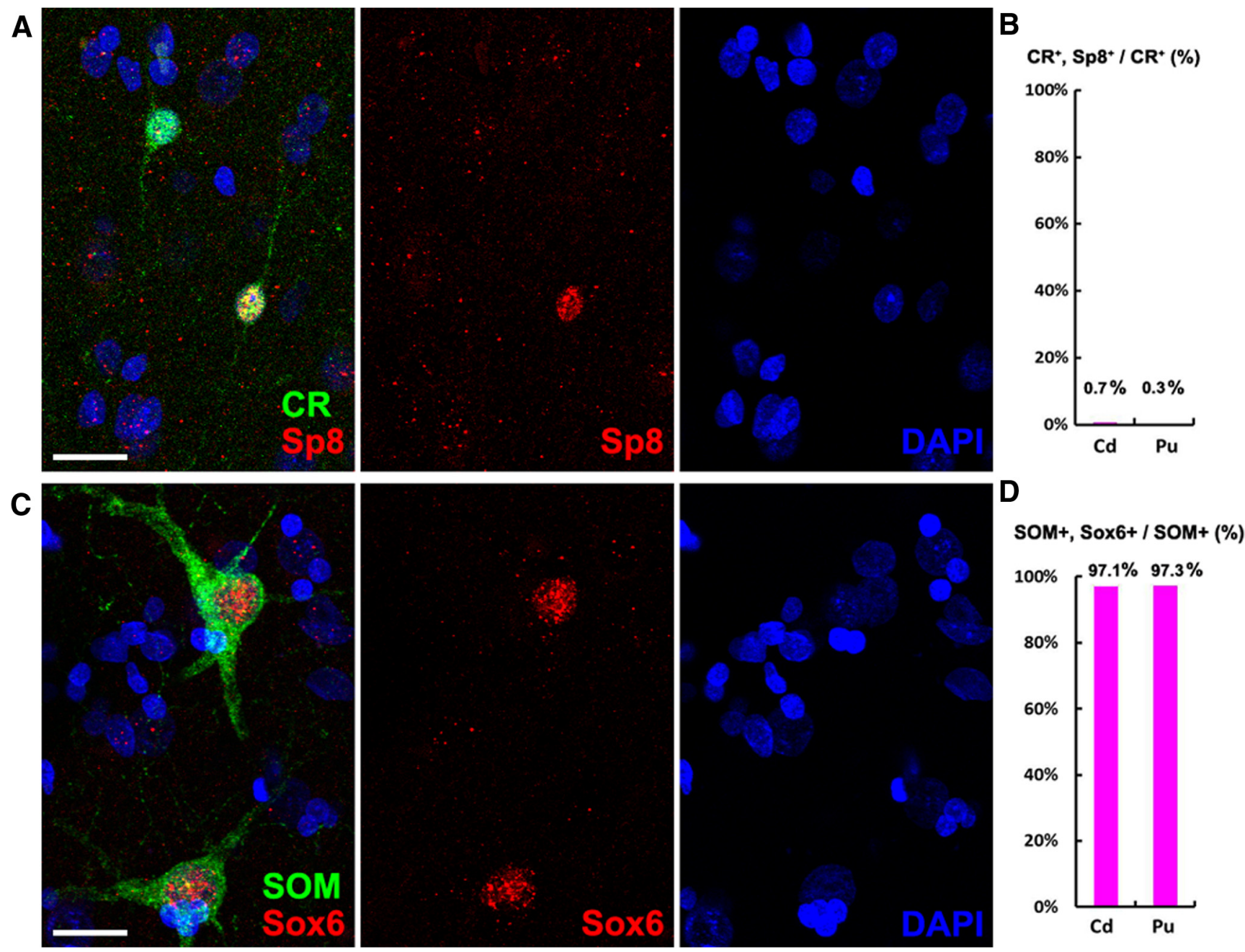

Figure 11. $C R+$ and SOM + interneurons in the adult human striatum are not derived from the adult SVZ. $A, B$, Very few CR + cells expressed Sp8 in the adult human striatum: caudate nucleus (Cd) and putamen (Pu). C, D, Nearly all SOM + cells in the adult human striatum expressed Sox6. Scale bars, $10 \mu \mathrm{m}$.

$\mathrm{SOM}+$ interneurons in the human striatum always expressed nNOS and NPY (Fig. 8E,F; Cicchetti et al., 2000). Only a small number of $\mathrm{CR}+$ interneurons are in the rodent striatum (Rymar et al., 2004; Liu et al., 2009; Wei et al., 2011), but they are the most abundant interneurons in the adult human striatum (Fig. 9A-E). This is consistent with previous observations (Cicchetti et al., 2000). However, we only observed very few Sp8+ cells in the adult human striatum (Fig. $8 G$, Fig. 9A-E). Doubleimmunostaining experiments revealed that $<1 \%$ of $C R+$ striatal interneurons expressed Sp8 (Fig. 9A-E; see Fig. $11 A, B$ ), although a mass of $\mathrm{Sp} 8+$ neuroblasts is present in the CGE, LGE, and RMS of the human fetal brain during development (Ma et al., 2013). We also found that none of the $\mathrm{ChAT}+, \mathrm{PV}+$, or $\mathrm{SOM}+$ striatal interneurons expressed Sp8 in the adult human striatum (data not shown). Because the vast majority of mouse striatal interneurons are derived from the MGE (Marin et al., 2000; Xu et al., 2008), we then examined the expression of Nkx2-1 and Sox6 in the adult human striatum. We did not observe Nkx2-1+ cells in the adult human striatum using immunohistochemistry staining in our samples (Fig. $8 H$ ). However, a small number of Sox6+ cells was observed (Fig. 8I), and most of the cells expressed SOM (Fig. 10A-E). Actually, our quantification data revealed that nearly all SOM+ interneurons expressed Sox6 in adult human striatum (Fig. 11C,D), suggesting that they are derived from the
MGE. We also found that all ChAT + cells in the human embryonic striatum at GW18 expressed Nkx2-1 (Fig. 12A-E). Because most neuroblasts in the adult human SVZ and RMS expressed Sp8, whereas NPY $+/ \mathrm{nNOS}+/ \mathrm{SOM}+$ and the vast majority of $\mathrm{CR}+$ interneurons in the human striatum did not express Sp8, it is unlikely that these $\mathrm{SOM}+$ and $\mathrm{CR}+$ striatal interneurons were generated from the progenitors of the adult SVZ. By contrast, we propose that most human striatal interneurons are derived from the MGE during embryonic stages, as they are in rodents.

Most interneurons in the rhesus monkey striatum are derived from the MGE

Two recent studies have observed Nkx2-1+ cells in the human and monkey fetal striatum (Hansen et al., 2013; Ma et al., 2013). Toward elucidating the origin of monkey striatal interneurons, we again used gene expression analyses using markers of the MGE (Nkx2-1 and Sox6), and LGE/CGE (Sp8) to provide evidence for the progenitor domain origin of these cells. We used three juvenile rhesus monkeys (P0, P6M, and P17M), as the expression of transcription factors is more easily detected in juvenile brain sections that are lacking lipofuscin. We first performed double immunostaining for Nkx2-1 with striatal interneuron markers. Virtually all ChAT + cells in the juvenile monkey striatum expressed Nkx2-1 (Fig. 13A,B), but not Sox6 (Fig. 13C,D). Al- 


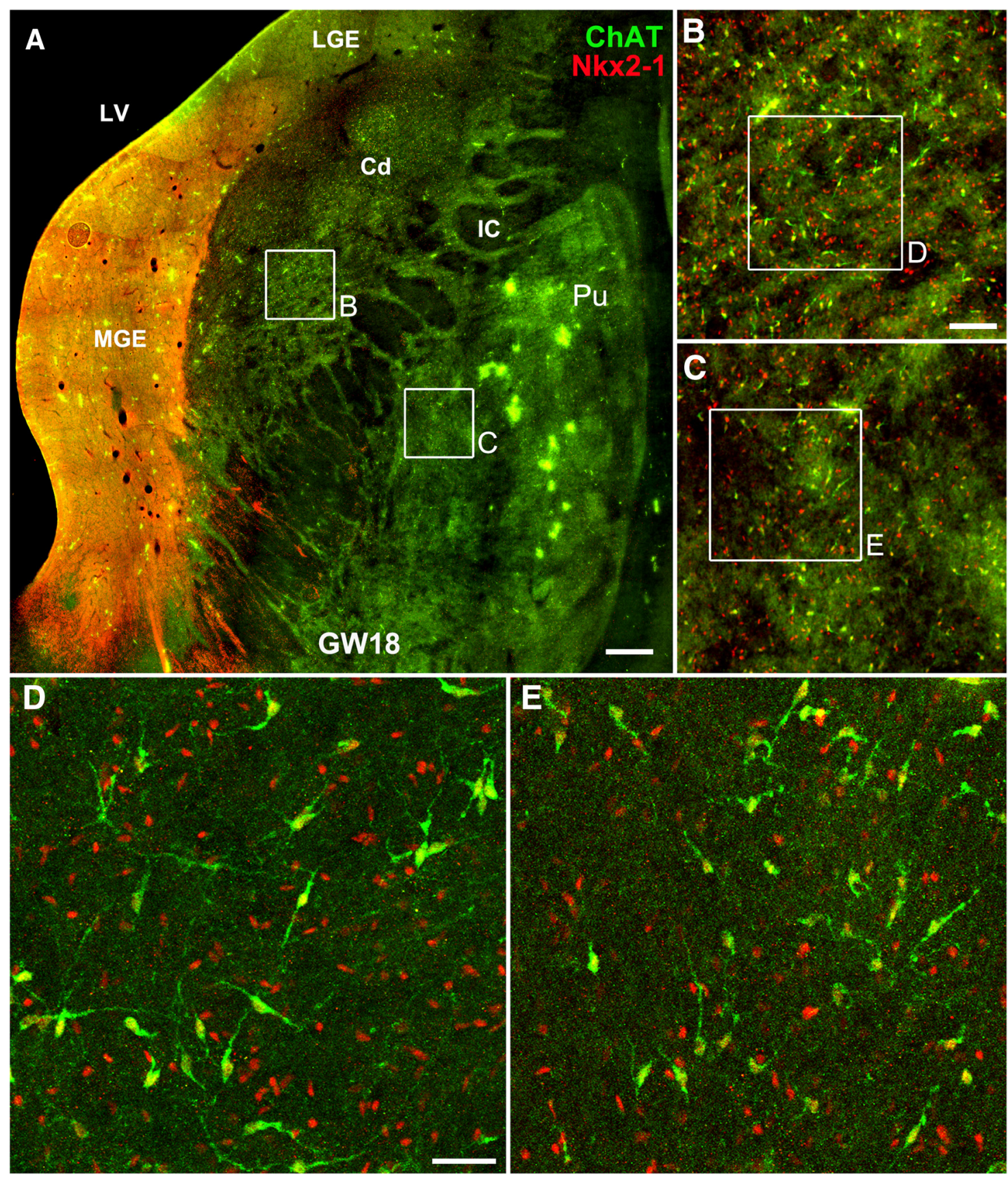

Figure 12. ChAT+ interneurons in the human striatum are generated from the MGE. $A$, ChAT/Nkx2-1 double-immunostained coronal section of GW18 human fetal brain. $B$, $C$, Highermagnification images of the boxed areas in $\boldsymbol{A}$. $\boldsymbol{D}, \boldsymbol{E}$, Higher-magnification images of the boxed areas in $\boldsymbol{B}$ and $\boldsymbol{C}$ show that all ChAT + cells expressed Nkx2-1 in the caudate nucleus (Cd) and putamen (Pu). LV, Lateral ventricle; IC, internal capsule. Scale bar: $A, 500 \mu \mathrm{m} ; \boldsymbol{B}, C, 100 \mu \mathrm{m} ; \boldsymbol{D}, E, 40 \mu \mathrm{m}$.

though only a small subpopulation of PV + cells were found in the $\mathrm{P} 0$ and $\mathrm{P} 6 \mathrm{M}$ monkey striatum compared with $\mathrm{P} 17 \mathrm{M}$ monkey striatum $(\sim 40 \mathrm{PV}+$ cells per striatal section at P0, $230 \mathrm{PV}+$ cells per striatal section at $\mathrm{P} 6 \mathrm{M}$, and $600 \mathrm{PV}+$ cells per section of P17M striatum), nearly all of these PV + cells expressed Nkx2-1 (Fig. 13E,F) and Sox6 (Fig. 13G,H). We also observed that $\sim 95 \% \mathrm{CR}+$ cells in the striatum expressed Nkx2-1 (Fig. 14A,B) and Sox6 (Fig. 14C,D), and $<5 \%$ of CR+ cells expressed Sp8 (Fig. 14E,F). Consistent within the mouse striatum, only a very small number of SOM+ cells in the monkey striatum expressed Nkx2-1 (Fig. 13 I,J; Marin et al., 2000), but nearly all of them expressed Sox6 (Fig. 13K,L). Once again, all SOM+ cells expressed nNOS and NPY in the monkey striatum (Fig. 14G-J;
Cicchetti et al., 2000). These gene expression analyses provide evidence that most interneurons in the rhesus monkey striatum are derived from the MGE and POA, except for a very small percentage of $\mathrm{CR}+$ striatal interneurons that are probably generated from the CGE and/or LGE.

\section{Lack of interneuron production in the adult rhesus monkey striatum}

To label newly born cells in the striatum, the S-phase marker BrdU was injected intraperitoneally into adult rhesus monkeys twice daily for $5 \mathrm{~d}$ and BrdU double immunostaining for neuronal markers were performed at 10 and 15 weeks after BrdU injection (Fig. 15A). Confocal analysis of two adult rhesus monkeys 

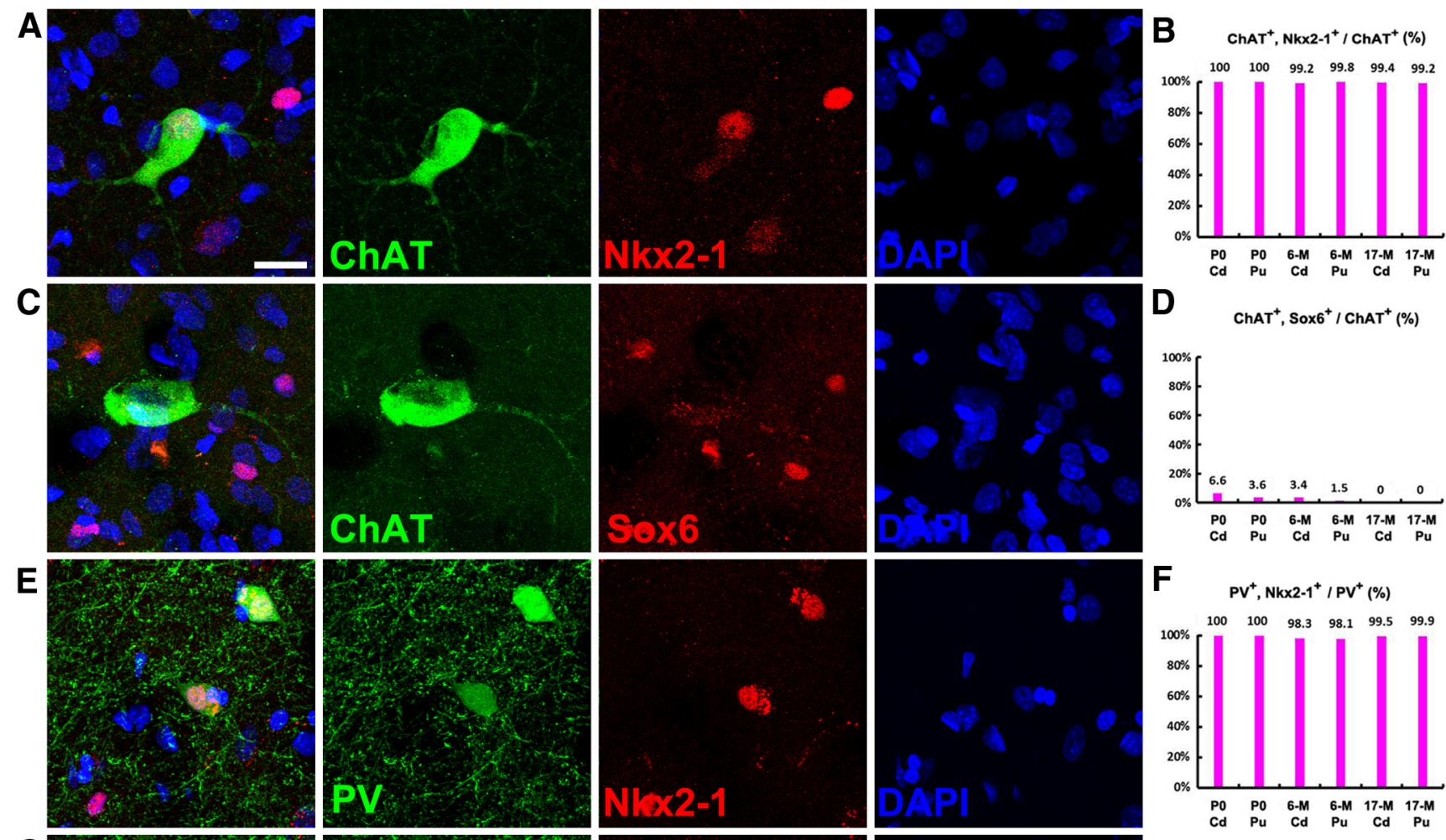

\section{D
${ }^{10}$
${ }^{6}$


2}

$\mathrm{ChAT}^{+}, \mathrm{SOXK}^{+} / \mathrm{ChAT}^{+}(\%)$
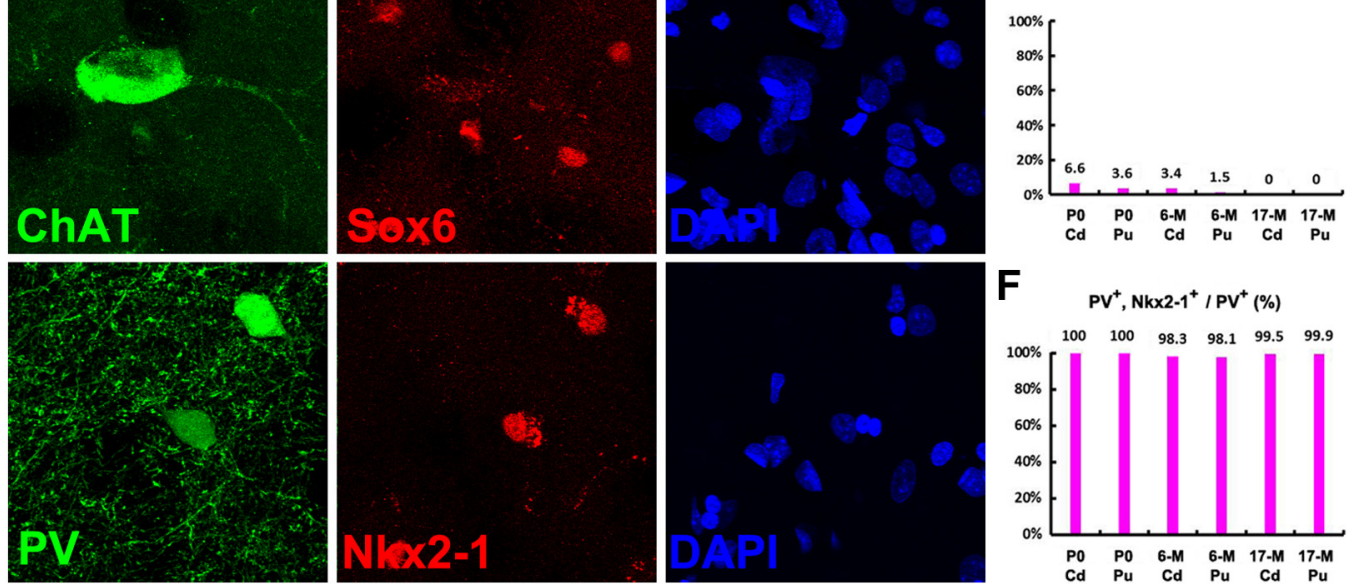

$F$

$\mathrm{PV}^{+}, \mathrm{Nkx2}^{-1} \mathbf{1}^{+} / \mathrm{PV}^{+}(\%)$
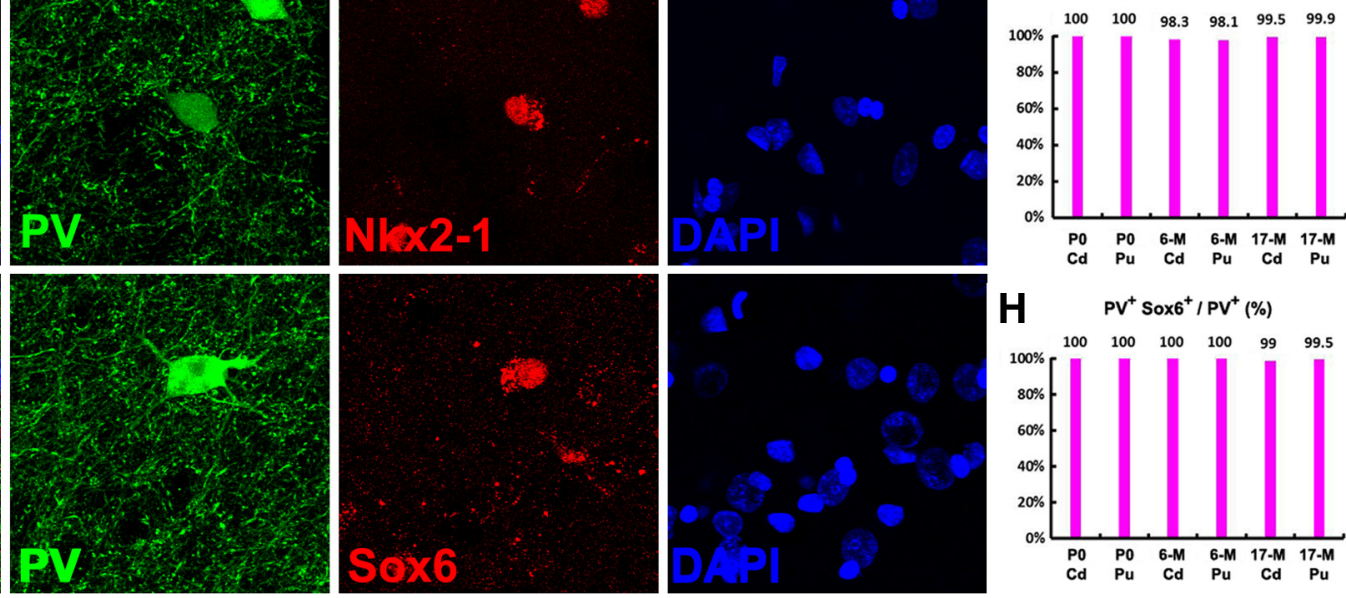

H

$\mathrm{PV}^{+} \mathrm{Sox6}^{+} / \mathrm{PV}^{+}(\%)$

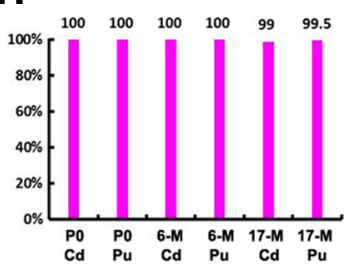

I
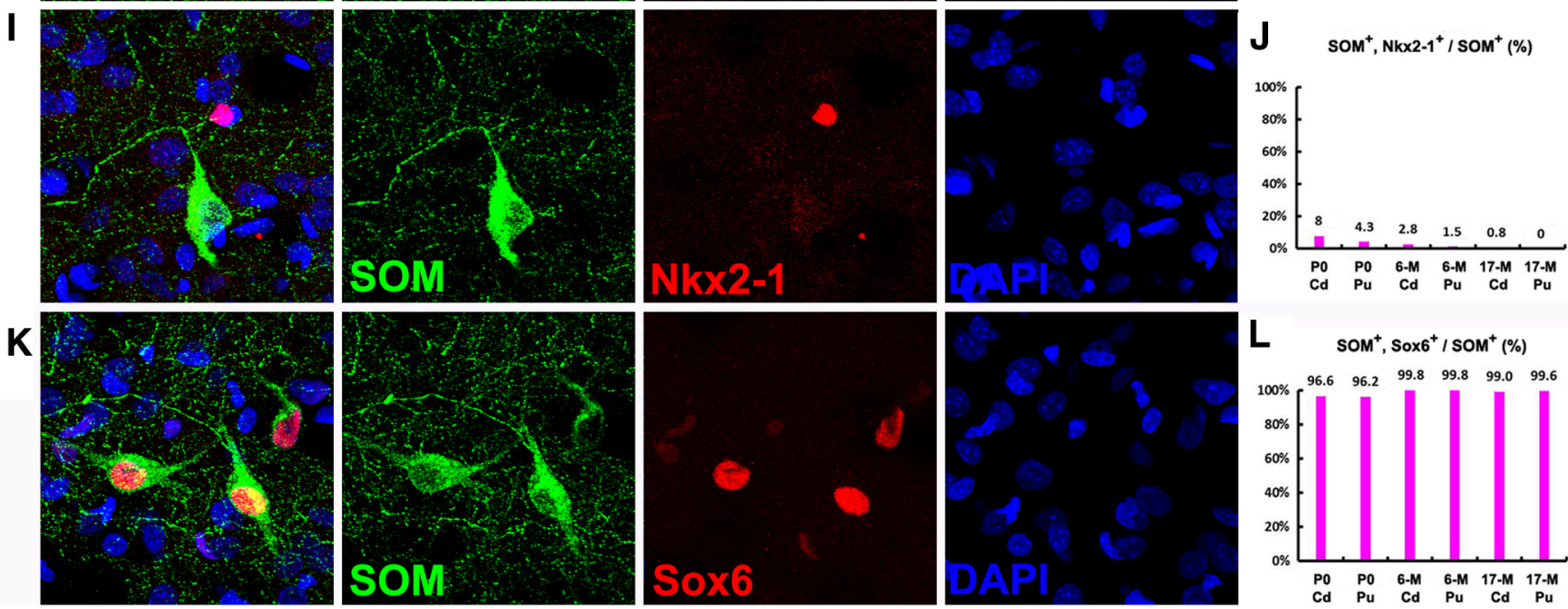

Figure 13. ChAT +, $\mathrm{PV}+$, and $\mathrm{SOM}+$ interneurons in the rhesus monkey striatum are derived from the MGE. $\mathbf{A}-\boldsymbol{D}$, Photomicrographs of double immunostained rhesus monkey brain sections at P6M. Nearly all ChAT + cells in the juvenile monkey (P0, P6M, and P17M) caudate nucleus (Cd) and putamen (Pu) expressed Nkx2-1, whereas they seldom expressed Sox6. E-H, Nearly all PV+ cells expressed Nkx2-1 and Sox6. I-L, Nearly all S0M + cells expressed Sox6, whereas they seldom expressed Nkx2-1. Scale bar, $20 \mu \mathrm{m}$.

revealed a few BrdU $+/ D c x+$ cells in the SVZ, and a few BrdU+ cells in the striatum, but no BrdU $+/ \mathrm{NeuN}+$ cells in the striatum were detected (Fig. 15B,C; $\sim 150 \mathrm{BrdU}+$ cells in the striatum were examined). Accordingly, we also did not observe BrdU+/ $\mathrm{CR}+$ or BrdU $+/ \mathrm{SOM}+$ cells in the striatum. This result strongly suggests that few if any new neurons are produced in the striatum of the adult rhesus monkey.

\section{Discussion}

A recent report suggests that new $\mathrm{CR}+$ and NPY + interneurons (also SOM $+/ \mathrm{nNOS}+$ interneurons) are generated in the human striatum throughout life; the turnover rate of striatal neurons within the renewing fraction is $\sim 2.7 \%$ per year in adulthood (Ernst et al., 2014). This turnover rate estimation is largely based on radiocarbon $14\left({ }^{14} \mathrm{C}\right)$ dating techniques. Unlike BrdU or io- 
A

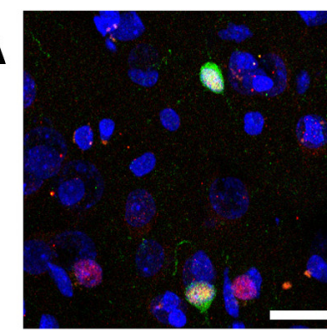

C

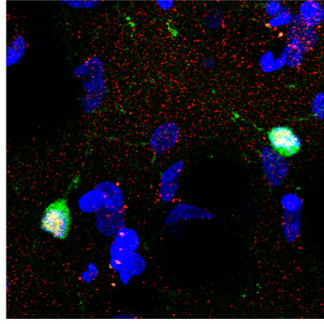

E

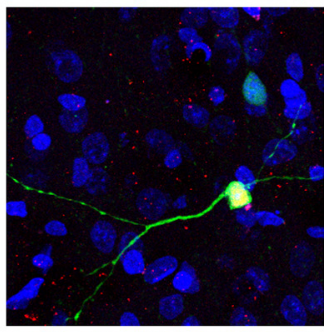

$\mathbf{G}$

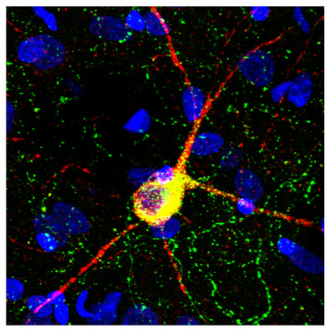

I

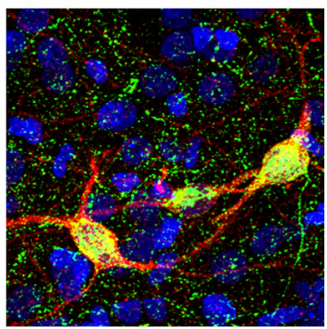

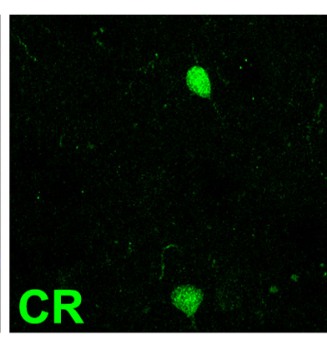
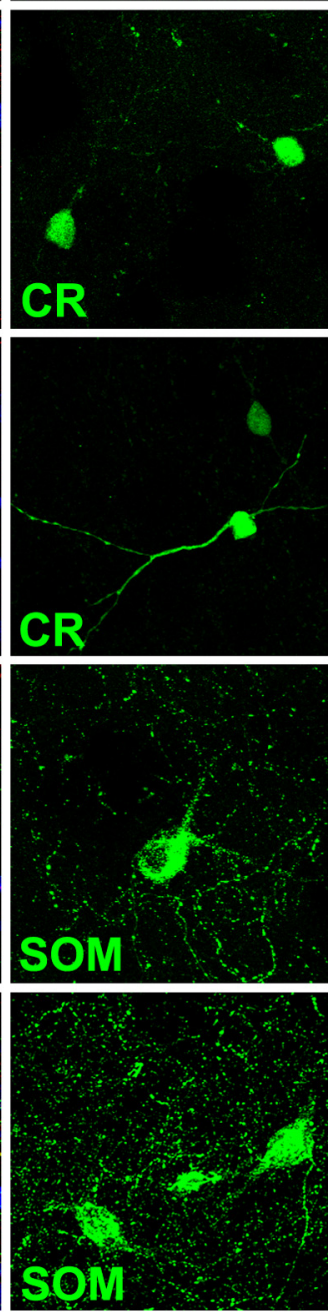
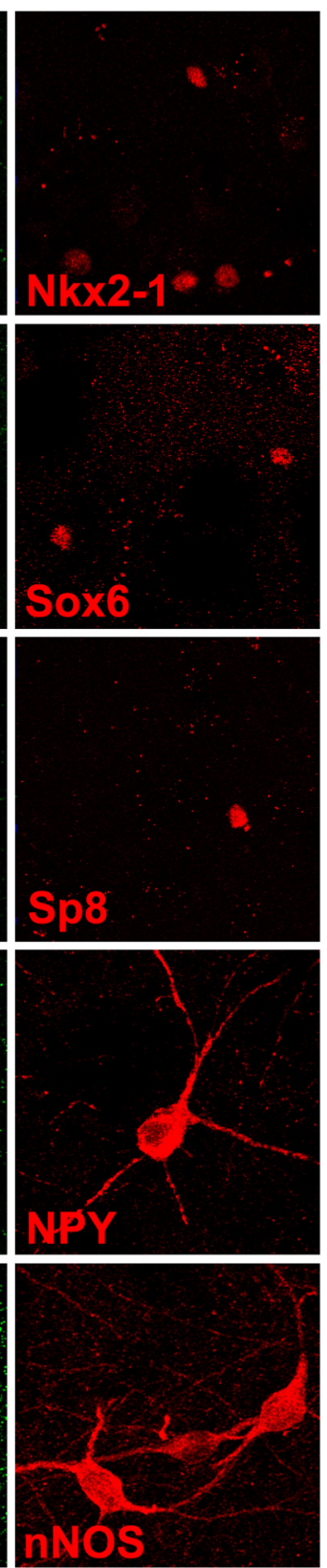

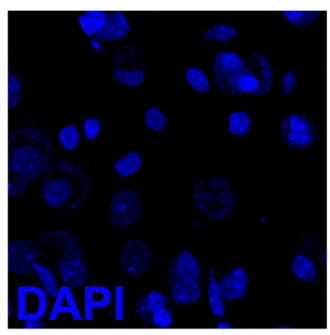

\section{B}
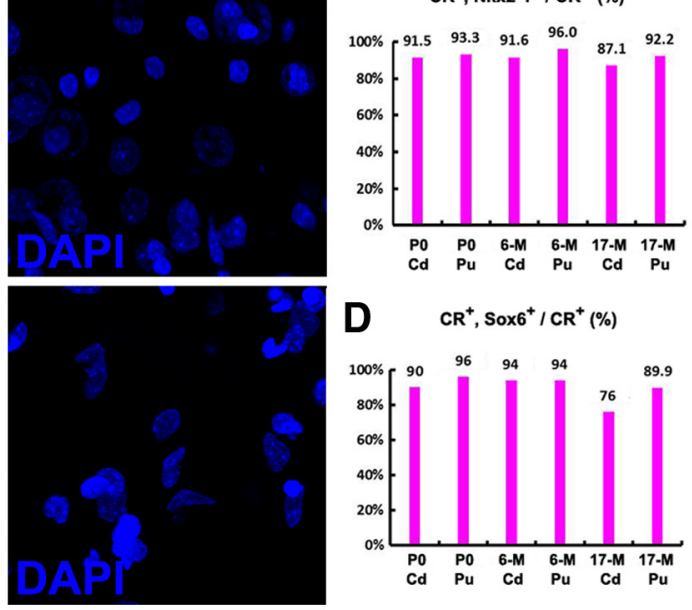

D $\mathrm{CR}^{+}, \mathrm{Sox6}^{*} / \mathrm{CR}^{*}(\%)$

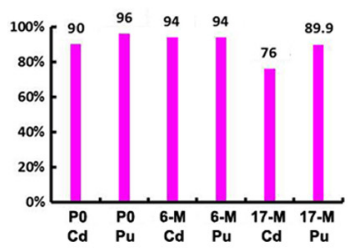

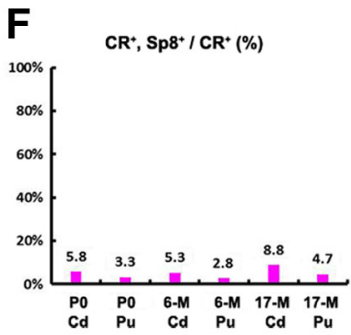

H $\operatorname{SOMM}^{+} \mathrm{NPY}^{+} / \mathrm{SOM}^{+}(\%)$
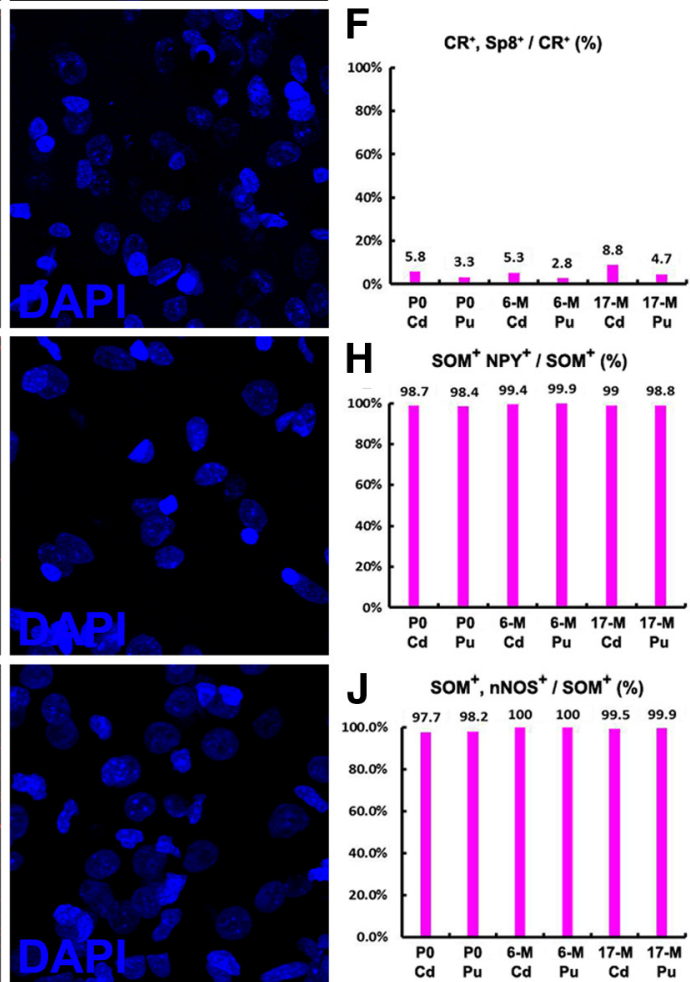

Figure 14. The majority of $C R+$ interneurons in the rhesus monkey striatum are derived from the MGE. $A-D$, Most $C R+$ cells in the juvenile monkey striatum expressed Nkx2-1 and Sox6. E, $F$, Less than $5 \%$ of CR + cells expressed Sp8. G-J, All SOM + interneurons in the rhesus monkey striatum expressed nNOS and NPY. Scale bars, $20 \mu \mathrm{m}$.

dodeoxyuridine labeling techniques, which can analyze newly born cells at a single-cell resolution, ${ }^{14} \mathrm{C}$ dating provides evidence for newly born cells at the level of large populations of cells. In the present study, our results do not support the above conclusion. By taking advantage of the continuous expression of Sp8 from the neuroblast stage (immature migratory neurons) through differentiation into mature interneurons, we have provided the following several strong pieces of evidence that adult primate SVZ does not generate interneurons for the striatum: (1) Sp8 is continuously expressed in the adult human and rhesus monkey SVZRMS-OB pathway, but only a very small number of Sp8+/CR+ interneurons are found in the adult monkey striatum, and, especially, Sp8+/CR + interneurons are extremely rare in the human striatum; (2) few if any Dcx + cells (neuroblasts) are detected in the adult human striatum; (3) the vast majority of interneurons in the human and rhesus monkey striatum are derived from the MGE and POA, expressing Nkx2.1 and/or Sox6, but not Sp8; and (4) BrdU-labeling experiments reveal few if any newly born neurons in the adult rhesus monkey striatum, consistent with the previous observations that used $\left[{ }^{3} \mathrm{H}\right]$ thymidinelabeling methods in rhesus monkeys (Brand and Rakic, 1979). Although we cannot exclude the possibility that neural stem/ progenitor cells in the adult human SVZ generate extremely rare new neurons for the striatum, on the basis of transcription factor expression and BrdU-labeling results, we conclude that the vast majority of interneurons in the human and monkey striatum are derived from the MGE during embryonic developmental stages without turnover in adulthood (Fig. 16).

Origins of interneurons in the human and monkey striatum In the mouse brain, it is well known that the MGE and POA, marked by $\mathrm{Nkx} 2-1$ expression, give rise not only to pallidal projection neurons, but also to cortical and striatal interneurons (Sussel et al., 1999; Marin et al., 2000; Xu et al., 2008; 
A
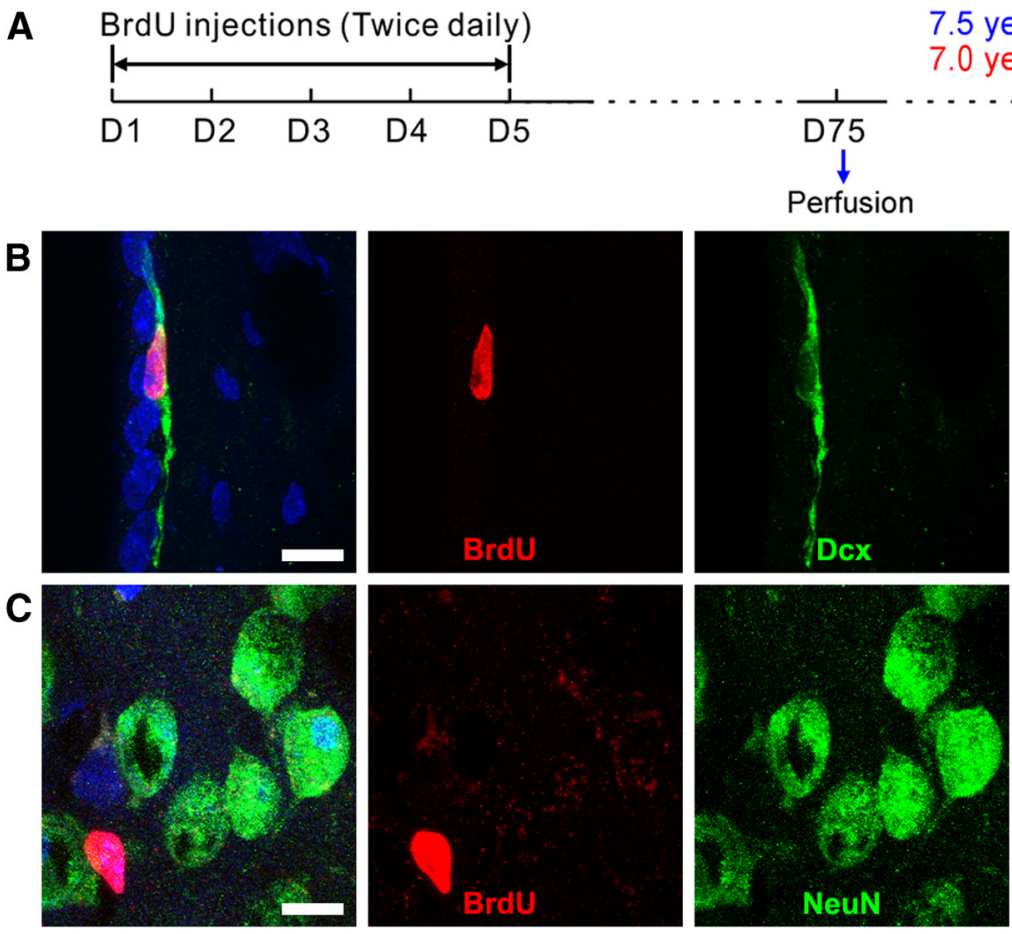

7.5 year-old monkey

7.0 year-old monkey
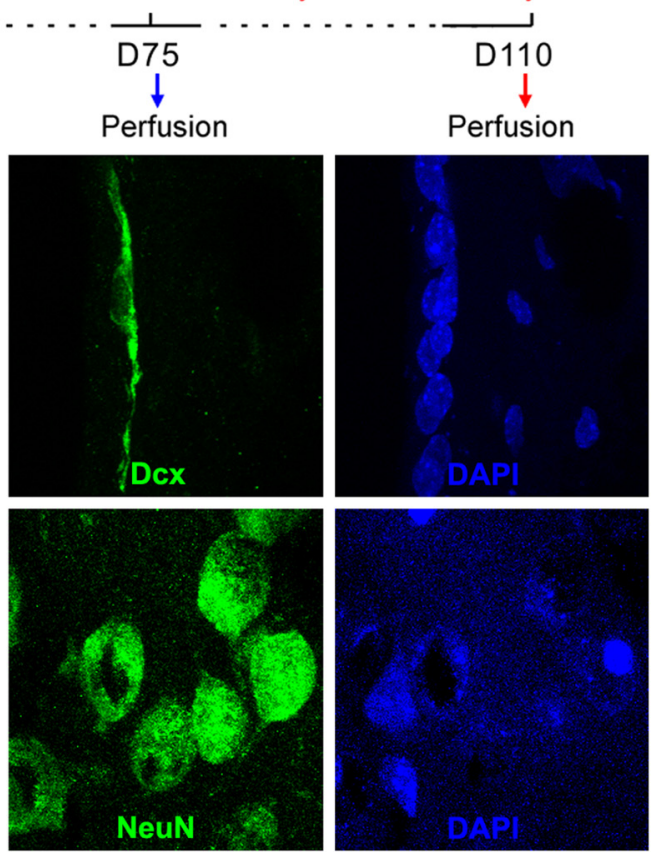

Figure 15. Newly born striatal neurons are not observed in the adult monkey striatum. $\boldsymbol{A}$, BrdU was injected intraperitoneally into two adult monkeys twice daily for $5 \mathrm{~d}$, and BrdU double immunostaining for neuronal markers was performed at 10 and 15 weeks after BrdU injection. $\boldsymbol{B}, \boldsymbol{C}, \mathrm{BrdU}+/ \mathrm{Dcx}+$ cells can still be observed in the SVZ (B) 15 weeks after BrdU injection, whereas $\mathrm{BrdU}+/ \mathrm{NeuN}+$ cells were not observed in the adult monkey striatum (C). Scale bars, $10 \mu \mathrm{m}$.

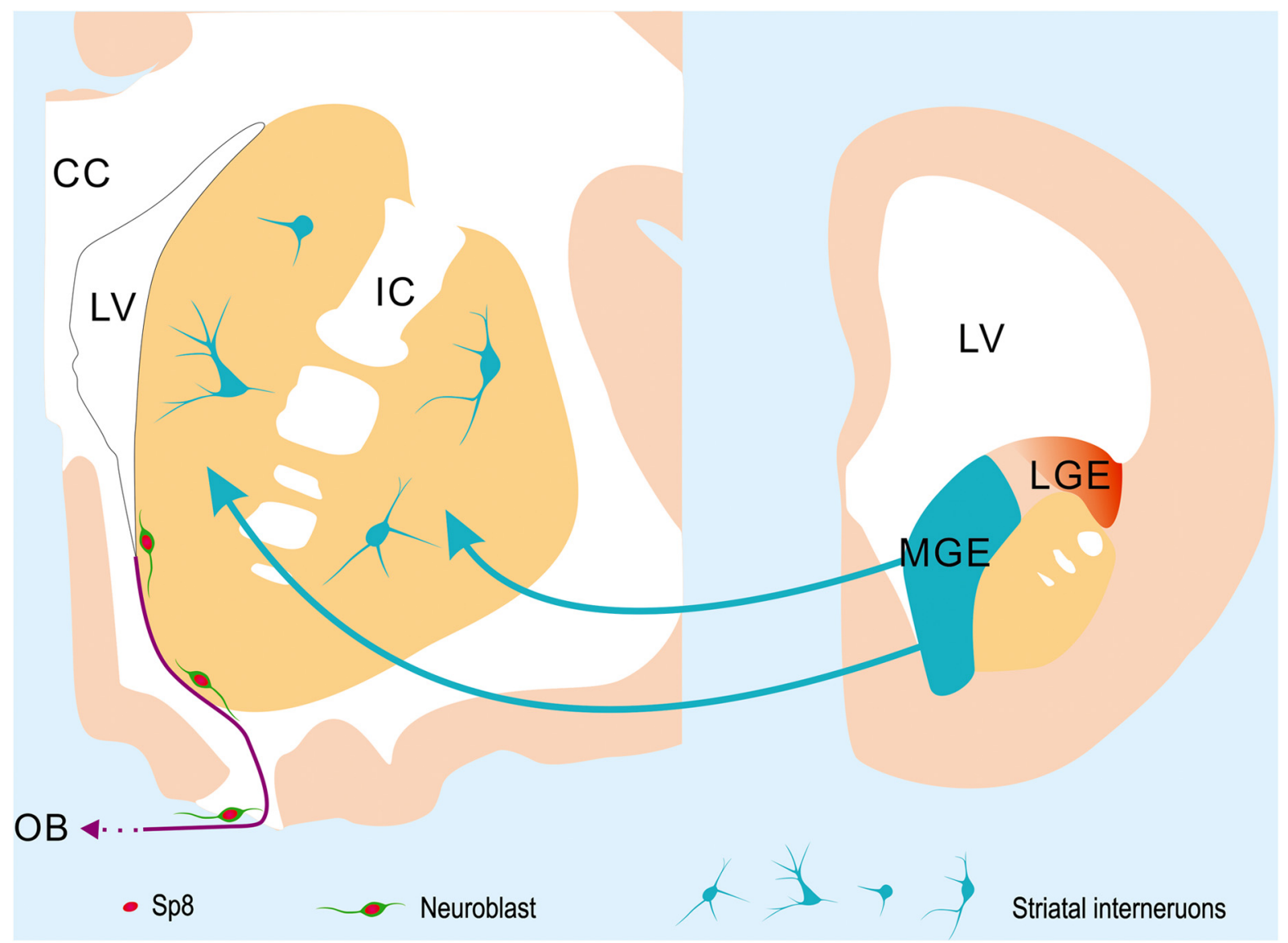

Figure 16. Proposed model for the origin of striatal interneurons in the human and monkey brain. The vast majority of interneurons in the adult human and monkey striatum are derived from the MGE during embryonic developmental stages. Very few neuroblasts are observed in the adult human SVZ and RMS. These neuroblasts express the transcription factor Sp8 and are likely destined for the $\mathrm{OB}$, as they are in adult monkeys and rodents. Neuroblasts were not observed in the adult human striatum in our study. 
Flandin et al., 2010; Nóbrega-Pereira et al., 2010). Human and monkey MGEs also express Nkx2-1 and give rise to $\sim 60-70 \%$ of neocortical interneurons (Hansen et al., 2013; Ma et al., 2013). Many Nkx2-1 + cells are also observed in the striatum of human and monkey fetal brain (Hansen et al., 2013; Ma et al., 2013), suggesting that human and monkey MGEs also produce interneurons for the striatum. In the present study, we found that all $\mathrm{ChAT}+, \mathrm{PV}+$, and most $\mathrm{CR}+$ interneurons in the juvenile rhesus monkey striatum express Nkx2-1, and only $<5 \% \mathrm{CR}+$ interneurons express Sp8. Although most SOM + / $\mathrm{NPY}+/ \mathrm{nNOS}+$ interneurons do not express Nkx2-1 in the monkey striatum, they express Sox6, another marker for most MGE-derived interneurons (Azim et al., 2009; Batista-Brito et al., 2009). This strongly suggests that the majority of rhesus monkey striatal interneurons are derived from the MGE and POA.

Although a subpopulation of Nkx2-1+ cells was observed in the adult rhesus monkey striatum (data not shown), we did not detect Nkx2-1 expression in the adult human striatum. We do not know the reason for this, but it is possible that detection of Nkx2-1 expression in this tissue may have been below the level of sensitivity of our assay. Note that Nkx2-1 striatal interneuron expression was detectable in the human fetus (Fig. 12; Hansen et al., 2013; Ma et al., 2013). Thus, perhaps Nkx2-1 expression is reduced as striatal interneurons mature. All ChAT + cells in the human fetal striatum express Nkx2-1, all SOM + cells in the adult human striatum express Sox6, and very few interneurons in the adult human striatum express Sp8, a hallmark of LGE- and CGEderived interneurons, but not MGE- or POA-derived interneurons (Ma et al., 2012, 2013), suggesting that the vast majority of striatal interneurons in the human brain are derived from the MGE and POA, just as they are in the mouse brain.

\section{The plasticity of neural stem cells in the adult mammalian SVZ}

In the normal adult rodent and monkey brain, SVZ neural stem cells mainly generate interneurons for the $\mathrm{OB}$, but not for the striatum or cortex (Alvarez-Buylla and Garcia-Verdugo, 2002; Rakic, 2002; Ihrie and Alvarez-Buylla, 2011). Additionally, in human fetal and neonatal brain, masses of putative migratory neuroblasts arranged in chains coalesce into the RMS, which connects the SVZ to the OB (Guerrero-Cázares et al., 2011; Sanai et al., 2011; Wang et al., 2011; Ma et al., 2013). In the adult human brain, we also observed putative neuroblasts that migrate as individual cells in the ventral SVZ and RMS (Wang et al., 2011); they express Sp8 and are likely destined for the OB.

It has been reported that neural stem cells in the adult rodent SVZ can generate a variety of neuronal subtypes following ischemic brain injury, including striatal PV+ interneurons, and striatal and hippocampal projection neurons (Arvidsson et al., 2002; Nakatomi et al., 2002; Parent et al., 2002; Teramoto et al., 2003; Thored et al., 2006). However, we proposed an alternative point of view. We observed that the majority of SVZ-derived newly born young and mature neurons in the ischemia-injured striatum in rodent brains continue to express Sp8 (Liu et al., 2009; Wei et al., 2011), suggesting that, following ischemic brain injury, a subpopulation of SVZ neuroblasts that normally migrate via the RMS to the $\mathrm{OB}$, can migrate into the damaged striatum; we proposed that these Sp8 + cells have not changed fate, but are ectopically located in the pathological tissue.
Previous studies also have reported that intracerebroventricular levels of brain-derived neurotrophic factor (BDNF) can significantly increase the production of $\mathrm{OB}$ interneurons and striatal projection neurons (Benraiss et al., 2001; Chmielnicki et al., 2004). However, another report (Galvão et al., 2008) has suggested that BDNF delivered to the ventricle does not enhance adult SVZ neurogenesis. Given that neural progenitors are also not readily respecified in the embryonic spinal cord (Mukouyama et al., 2006) and neocortex (Shen et al., 2006), the potential in vivo cell fate plasticity of adult SVZ neural stem cells has to be considered with caution.

Few if any newly born neurons are detected in the adult rodent and rhesus monkey striatum (Fig. 15; Brand and Rakic, 1979; Liu et al., 2009). This needs to be reconciled with the recent assertion that there are constantly generating interneurons in the adult human striatum, with $25 \%$ striatal neuron turnover (Ernst et al., 2014). Moreover, they also showed that these newly born striatal interneurons are preferentially depleted in individuals with Huntington's disease (Ernst et al., 2014), although this disease is mainly characterized by the progressive loss of striatal projection neurons. Given the divergence of these results from those observed in rodents and monkeys, one needs to be circumspect about potential explanations for these results, and their implications for disease mechanisms and therapies.

\section{References}

Alvarez-Buylla A, Garcia-Verdugo JM (2002) Neurogenesis in adult subventricular zone. J Neurosci 22:629-634. Medline

Anderson SA, Qiu M, Bulfone A, Eisenstat DD, Meneses J, Pedersen R, Rubenstein JL (1997) Mutations of the homeobox genes Dlx-1 and Dlx-2 disrupt the striatal subventricular zone and differentiation of late born striatal neurons. Neuron 19:27-37. CrossRef Medline

Arvidsson A, Collin T, Kirik D, Kokaia Z, Lindvall O (2002) Neuronal replacement from endogenous precursors in the adult brain after stroke. Nat Med 8:963-970. CrossRef Medline

Azim E, Jabaudon D, Fame RM, Macklis JD (2009) SOX6 controls dorsal progenitor identity and interneuron diversity during neocortical development. Nat Neurosci 12:1238-1247. CrossRef Medline

Batista-Brito R, Rossignol E, Hjerling-Leffler J, Denaxa M, Wegner M, Lefebvre V, Pachnis V, Fishell G (2009) The cell-intrinsic requirement of Sox6 for cortical interneuron development. Neuron 63:466-481. CrossRef Medline

Bédard A, Lévesque M, Bernier PJ, Parent A (2002) The rostral migratory stream in adult squirrel monkeys: contribution of new neurons to the olfactory tubercle and involvement of the antiapoptotic protein Bcl-2. Eur J Neurosci 16:1917-1924. CrossRef Medline

Benraiss A, Chmielnicki E, Lerner K, Roh D, Goldman SA (2001) Adenoviral brain-derived neurotrophic factor induces both neostriatal and olfactory neuronal recruitment from endogenous progenitor cells in the adult forebrain. J Neurosci 21:6718-6731. Medline

Brand S, Rakic P (1979) Genesis of the primate neostriatum: [3H]thymidine autoradiographic analysis of the time of neuron origin in the rhesus monkey. Neuroscience 4:767-778. CrossRef Medline

Chen R, Lin C, You Y, Liu F (2012) Characterization of immature and mature 5-hydroxytryptamine $3 \mathrm{~A}$ receptor-expressing cells within the adult SVZ-RMS-OB system. Neuroscience 227:180-190. CrossRef Medline

Chmielnicki E, Benraiss A, Economides AN, Goldman SA (2004) Adenovirally expressed noggin and brain-derived neurotrophic factor cooperate to induce new medium spiny neurons from resident progenitor cells in the adult striatal ventricular zone. J Neurosci 24:2133-2142. CrossRef Medline

Cicchetti F, Prensa L, Wu Y, Parent A (2000) Chemical anatomy of striatal interneurons in normal individuals and in patients with Huntington's disease. Brain Res Brain Res Rev 34:80-101. CrossRef Medline

Deacon TW, Pakzaban P, Isacson O (1994) The lateral ganglionic eminence is the origin of cells committed to striatal phenotypes: neural transplan- 
tation and developmental evidence. Brain Res 668:211-219. CrossRef Medline

Doetsch F, Caillé I, Lim DA, García-Verdugo JM, Alvarez-Buylla A (1999) Subventricular zone astrocytes are neural stem cells in the adult mammalian brain. Cell 97:703-716. CrossRef Medline

Ernst A, Alkass K, Bernard S, Salehpour M, Perl S, Tisdale J, Possnert G, Druid H, Frisén J (2014) Neurogenesis in the striatum of the adult human brain. Cell 156:1072-1083. CrossRef Medline

Fishell G, Rudy B (2011) Mechanisms of inhibition within the telencephalon: "where the wild things are." Annu Rev Neurosci 34:535-567. CrossRef

Flames N, Pla R, Gelman DM, Rubenstein JL, Puelles L, Marín O (2007) Delineation of multiple subpallial progenitor domains by the combinatorial expression of transcriptional codes. J Neurosci 27:9682-9695. CrossRef Medline

Flandin P, Kimura S, Rubenstein JL (2010) The progenitor zone of the ventral medial ganglionic eminence requires $\mathrm{Nkx} 2-1$ to generate most of the globus pallidus but few neocortical interneurons. J Neurosci 30:28122823. CrossRef Medline

Galvão RP, Garcia-Verdugo JM, Alvarez-Buylla A (2008) Brain-derived neurotrophic factor signaling does not stimulate subventricular zone neurogenesis in adult mice and rats. J Neurosci 28:13368-13383. CrossRef Medline

Gerfen CR (1992) The neostriatal mosaic: multiple levels of compartmental organization. Trends Neurosci 15:133-139. CrossRef Medline

Gil-Perotin S, Duran-Moreno M, Belzunegui S, Luquin MR, Garcia-Verdugo JM (2009) Ultrastructure of the subventricular zone in Macaca fascicularis and evidence of a mouse-like migratory stream. J Comp Neurol 514:533-554. CrossRef Medline

Guerrero-Cázares H, Gonzalez-Perez O, Soriano-Navarro M, ZamoraBerridi G, García-Verdugo JM, Quinoñes-Hinojosa A (2011) Cytoarchitecture of the lateral ganglionic eminence and rostral extension of the lateral ventricle in the human fetal brain. J Comp Neurol 519:11651180. CrossRef Medline

Hansen DV, Lui JH, Flandin P, Yoshikawa K, Rubenstein JL, Alvarez-Buylla A, Kriegstein AR (2013) Non-epithelial stem cells and cortical interneuron production in the human ganglionic eminences. Nat Neurosci 16: 1576-1587. CrossRef Medline

Ihrie RA, Alvarez-Buylla A (2011) Lake-front property: a unique germinal niche by the lateral ventricles of the adult brain. Neuron 70:674-686. CrossRef Medline

Kawaguchi Y, Wilson CJ, Augood SJ, Emson PC (1995) Striatal interneurones: chemical, physiological and morphological characterization. Trends Neurosci 18:527-535. CrossRef Medline

Kornack DR, Rakic P (2001a) Cell proliferation without neurogenesis in adult primate neocortex. Science 294:2127-2130. CrossRef Medline

Kornack DR, Rakic P (2001b) The generation, migration, and differentiation of olfactory neurons in the adult primate brain. Proc Natl Acad Sci U S A 98:4752-4757. CrossRef Medline

Kriegstein A, Alvarez-Buylla A (2009) The glial nature of embryonic and adult neural stem cells. Annu Rev Neurosci 32:149-184. CrossRef Medline

Leisman G, Melillo R (2013) The basal ganglia: motor and cognitive relationships in a clinical neurobehavioral context. Rev Neurosci 24:9-25. CrossRef Medline

Li X, Sun C, Lin C, Ma T, Madhavan MC, Campbell K, Yang Z (2011) The transcription factor $\mathrm{Sp} 8$ is required for the production of parvalbuminexpressing interneurons in the olfactory bulb. J Neurosci 31:8450-8455. CrossRef Medline

Liu F, You Y, Li X, Ma T, Nie Y, Wei B, Li T, Lin H, Yang Z (2009) Brain injury does not alter the intrinsic differentiation potential of adult neuroblasts. J Neurosci 29:5075-5087. CrossRef Medline

Long JE, Cobos I, Potter GB, Rubenstein JL (2009) Dlx1\&2 and Mash1 transcription factors control MGE and CGE patterning and differentiation through parallel and overlapping pathways. Cereb Cortex 19 [Suppl 1]: i96-i106. CrossRef

Ma T, Zhang Q, Cai Y, You Y, Rubenstein JL, Yang Z (2012) A subpopulation of dorsal lateral/caudal ganglionic eminence-derived neocortical interneurons expresses the transcription factor Sp8. Cereb Cortex 22: 2120-2130. CrossRef Medline

Ma T, Wang C, Wang L, Zhou X, Tian M, Zhang Q, Zhang Y, Li J, Liu Z, Cai Y, Liu F, You Y, Chen C, Campbell K, Song H, Ma L, Rubenstein JL, Yang
Z (2013) Subcortical origins of human and monkey neocortical interneurons. Nat Neurosci 16:1588-1597. CrossRef Medline

Marin O, Anderson SA, Rubenstein JL (2000) Origin and molecular specification of striatal interneurons. J Neurosci 20:6063-6076. Medline

Merkle FT, Fuentealba LC, Sanders TA, Magno L, Kessaris N, Alvarez-Buylla A (2014) Adult neural stem cells in distinct microdomains generate previously unknown interneuron types. Nat Neurosci 17:207-214. CrossRef Medline

Mirzadeh Z, Merkle FT, Soriano-Navarro M, Garcia-Verdugo JM, AlvarezBuylla A (2008) Neural stem cells confer unique pinwheel architecture to the ventricular surface in neurogenic regions of the adult brain. Cell Stem Cell 3:265-278. CrossRef Medline

Mukouyama YS, Deneen B, Lukaszewicz A, Novitch BG, Wichterle H, Jessell TM, Anderson DJ (2006) Olig2 + neuroepithelial motoneuron progenitors are not multipotent stem cells in vivo. Proc Natl Acad Sci U S A 103:1551-1556. CrossRef Medline

Nakatomi H, Kuriu T, Okabe S, Yamamoto S, Hatano O, Kawahara N, Tamura A, Kirino T, Nakafuku M (2002) Regeneration of hippocampal pyramidal neurons after ischemic brain injury by recruitment of endogenous neural progenitors. Cell 110:429-441. CrossRef Medline

Nóbrega-Pereira S, Gelman D, Bartolini G, Pla R, Pierani A, Marín O (2010) Origin and molecular specification of globus pallidus neurons. J Neurosci 30:2824-2834. CrossRef Medline

Olsson M, Campbell K, Wictorin K, Björklund A (1995) Projection neurons in fetal striatal transplants are predominantly derived from the lateral ganglionic eminence. Neuroscience 69:1169-1182. CrossRef Medline

Parent JM, Vexler ZS, Gong C, Derugin N, Ferriero DM (2002) Rat forebrain neurogenesis and striatal neuron replacement after focal stroke. Ann Neurol 52:802-813. CrossRef Medline

Pencea V, Bingaman KD, Freedman LJ, Luskin MB (2001) Neurogenesis in the subventricular zone and rostral migratory stream of the neonatal and adult primate forebrain. Exp Neurol 172:1-16. CrossRef Medline

Rakic P (2002) Neurogenesis in adult primate neocortex: an evaluation of the evidence. Nat Rev Neurosci 3:65-71. CrossRef Medline

Rymar VV, Sasseville R, Luk KC, Sadikot AF (2004) Neurogenesis and stereological morphometry of calretinin-immunoreactive GABAergic interneurons of the neostriatum. J Comp Neurol 469:325-339. CrossRef Medline

Sanai N, Nguyen T, Ihrie RA, Mirzadeh Z, Tsai HH, Wong M, Gupta N, Berger MS, Huang E, Garcia-Verdugo JM, Rowitch DH, Alvarez-Buylla A (2011) Corridors of migrating neurons in the human brain and their decline during infancy. Nature 478:382-386. CrossRef Medline

Sawamoto K, Hirota Y, Alfaro-Cervello C, Soriano-Navarro M, He X, Hayakawa-Yano Y, Yamada M, Hikishima K, Tabata H, Iwanami A, Nakajima K, Toyama Y, Itoh T, Alvarez-Buylla A, Garcia-Verdugo JM, Okano H (2011) Cellular composition and organization of the subventricular zone and rostral migratory stream in the adult and neonatal common marmoset brain. J Comp Neurol 519:690-713. CrossRef Medline

Shen Q, Wang Y, Dimos JT, Fasano CA, Phoenix TN, Lemischka IR, Ivanova NB, Stifani S, Morrisey EE, Temple S (2006) The timing of cortical neurogenesis is encoded within lineages of individual progenitor cells. Nat Neurosci 9:743-751. CrossRef Medline

Sussel L, Marin O, Kimura S, Rubenstein JL (1999) Loss of Nkx2.1 homeobox gene function results in a ventral to dorsal molecular respecification within the basal telencephalon: evidence for a transformation of the pallidum into the striatum. Development 126:3359-3370. Medline

Teramoto T, Qiu J, Plumier JC, Moskowitz MA (2003) EGF amplifies the replacement of parvalbumin-expressing striatal interneurons after ischemia. J Clin Invest 111:1125-1132. CrossRef Medline

Thored P, Arvidsson A, Cacci E, Ahlenius H, Kallur T, Darsalia V, Ekdahl CT, Kokaia Z, Lindvall O (2006) Persistent production of neurons from adult brain stem cells during recovery after stroke. Stem Cells 24:739-747. CrossRef Medline

Vogt D, Hunt RF, Mandal S, Sandberg M, Silberberg SN, Nagasawa T, Yang Z, Baraban SC, Rubenstein JL (2014) Lhx6 directly regulates Arx and CXCR7 to determine cortical interneuron fate and laminar position. Neuron 82:350-364. CrossRef Medline

Waclaw RR, Allen ZJ 2nd, Bell SM, Erdélyi F, Szabó G, Potter SS, Campbell K (2006) The zinc finger transcription factor Sp8 regulates the generation 
and diversity of olfactory bulb interneurons. Neuron 49:503-516. CrossRef Medline

Waclaw RR, Wang B, Pei Z, Ehrman LA, Campbell K (2009) Distinct temporal requirements for the homeobox gene Gsx2 in specifying striatal and olfactory bulb neuronal fates. Neuron 63:451-465. CrossRef Medline

Wang C, Liu F, Liu YY, Zhao CH, You Y, Wang L, Zhang J, Wei B, Ma T, Zhang Q, Zhang Y, Chen R, Song H, Yang Z (2011) Identification and characterization of neuroblasts in the subventricular zone and rostral migratory stream of the adult human brain. Cell Res 21:1534-1550. CrossRef Medline

Wei B, Nie Y, Li X, Wang C, Ma T, Huang Z, Tian M, Sun C, Cai Y, You Y, Liu F, Yang Z (2011) Emxl-expressing neural stem cells in the subventricu- lar zone give rise to new interneurons in the ischemic injured striatum. Eur J Neurosci 33:819-830. CrossRef Medline

Wichterle H, Turnbull DH, Nery S, Fishell G, Alvarez-Buylla A (2001) In utero fate mapping reveals distinct migratory pathways and fates of neurons born in the mammalian basal forebrain. Development 128:37593771. Medline

Xu Q, Tam M, Anderson SA (2008) Fate mapping Nkx2.1-lineage cells in the mouse telencephalon. J Comp Neurol 506:16-29. CrossRef Medline Young KM, Fogarty M, Kessaris N, Richardson WD (2007) Subventricular zone stem cells are heterogeneous with respect to their embryonic origins and neurogenic fates in the adult olfactory bulb. J Neurosci 27:82868296. CrossRef Medline 